\title{
MODEL INTEGRASI LEMBAGA PERWAKILAN UNTUK PENDAFTARAN SEBAGAI ALTERNATIF PENDAFTARAN \\ UNTUK MEMPEROLEH PERLINDUNGAN HUKUM INDIKASI GEOGRAFIS UBI CILEMBU
}

\author{
Tatty A. Ramli dan Yeti Sumiyati
}

\begin{abstract}
Abstrak
Geographical Indication functioning like a trademark, such particular names of locations as Geographical Indication are legally protected. Adopting the first to file system in Indonesia the right for Geographical Indication are given by the state to the first registrant that has passed administrative and substantive. The first registered is protected. Untill today there is still no registration that has been submitted for Cilembu as Geographical Indication. This is mainly due to the fact that the logbook is a principal requirement for registration should describe a comprehensive description of the product Ubi Cilembu. I $t$ would not possible to be filled by only one of representative body that indicated in Presidential Decree No. 51/2007 on Geographical Indication. The stakeholders of Cilembu should strongly convinced that it is necessary to developed a model of body which integrated all stakeholders concern, so the Log Book could be completed and the registration is proposed immediately.
\end{abstract}

Kata kunci: indikasi geografis, pendaftaran, integrasi perwakilan, ubi cilembu

\section{Pendahuluan}

Disahkannya Peraturan Pemerintah Nomor 51 tahun 2007 tentang Indikasi Geografis sebagai peraturan pelaksanan dari UU Nomor 15 tahun 2001 tentang Merek, memberikan harapan baru bagi wilayah-wilayah di Indonesia yang kaya akan hasil alam dan kerajinan dengan kualitas dan karakteristik khas yang dapat digunakan untuk membedakan barang satu dengan barang lainnya yang memiliki kategori sama di wilayah lain, untuk mendapatkan perlindungan hukum dan memberikan manfaat ekonomi bagi masyarakatnya.

Pada dasarnya, Indikasi-geografis melindungi produk hasil pertanian, produk olahan, hasil kerajinan tangan, atau barang lainnya yang kualitas dan karakteristik khasnya dipengaruhi oleh lingkungan geografis setempat. 
Artinya, terdapat hubungan atau pertautan antara produk tersebut dengan tempat produk berasal.

Sebagai negara kepulauan yang kaya akan pengetahuan, tradisi, dan budaya, serta iklim tropis yang menghasilkan berbagai macam barang yang memiliki potensi ekonomi yang tidak kecil, sudah seharusnya produk-produk tersebut dilindungi. Melalui perlindungan Indikasi-geografis yang optimal tidak saja kelestarian lingkungan diharapkan dapat terjaga, pemberdayaan sumber daya alam dan manusia di daerah diharapkan dapat lebih dimaksimalkan. ${ }^{1}$ Contoh produk Indikasi Geografis di Indonesia yang sampai saat ini belum mendapatkan perlindungan adalah Kopi Toraja, Ubi Cilembu, Beras Delanggu, Mangga Indramayu, Peuyeum Bandung, Tahu Sumedang, ${ }^{2}$ Beras Cianjur, ${ }^{3}$ dsb. Baru Kopi Arabika Kintamani Bali saja yang telah didaftarkan. 4

Pengembangan Indikasi-geografis bersifat sangat menguntungkan karena disatu sisi, perlindungan hukum bagi produk khas daerah di Indonesia dapat meningkatkan nilai tambah dan mendorong daerah untuk meningkatkan produk unggulan mereka. Di sisi lain, perlindungan Indikasigeografis bersifat komunal (dimiliki oleh masyarakat) dan bukan oleh perseorangan. ${ }^{5}$ Tidak seperti perlindungan HKI yang lain, perlindungan Indikasi-geografis bersifat permanen asal ciri khas dan kualitas barang yang dilindungi masih tetap sama dan terjaga.

\section{${ }^{1}$ Penjelasan PP Nomor 51 Tahun 2007 tentang Indikasi Geografis.}

${ }^{2}$ Emawati Junus, Pentingnya Perlindungan Indikasi Geografis sebagai Bagian dari HKI dan Pelaksanaannya di Indonesia, Makalah pada Seminar Nasional "Perlindungan Indikasi Geografis di Indonesia, Jakarta, 6-7 Desember 2004.

${ }^{3}$ Dalam Harian Umum Galamedia, Selasa 26 Juni 2007. Dinas Pertanian (Distan) $\mathrm{Kab}$. Bandung menemukan fakta saat melakukan pemantauan langsung ke lapangan, bahwa ternyata beras "aspal" Pandanwangi atau beras karungan berlabel beras Pandanwangi Cianjur yang dijual sejumlah petani atau pedagang beras di pasaran sekarang, ternyata berasal dari $\mathrm{Kab}$. Bandung. Beras tersebut adalah beras dari varietas lain dan tumbuh di Kabupaten Bandung yang disemprot essen pandan.

${ }^{4}$ Deklarasi sekaligus penyerahan sertifikat pendaftaran Indikasi-geografis pertama di Indonesia akan diberikan oleh Dirjen HKI kepada Masyarakat Perlindungan Indikasi Geografis (MPIG) Kopi Arabika Kintamani Bali bertepatan dengan Seminar Nasional tentang Indikasi Geografis yang diselenggarakan pada 11-13 Desember 2008 yang lalu di Bali.

${ }^{5}$ Peningkatan Nilai Tambah Komoditas Indonesia Dengan Pengembangan Indikasi Geografis, Direktorat Kerjasama Dan Perdagangan Internasional 2004, <http://ditjenkpi.depdag.go.id/website_kpi/files/content/2/Indikasi_Geografis_Final20060106 141403.doc.> 
Permasalahannya adalah di Indonesia, Indikasi-geografis belum digunakan untuk memberikan hasil yang optimal. Tidak otomatisnya perlindungan hukum Indikasi-geografis melekat pada produk dengan kualitas dan karakteristik khas yang dapat digunakan untuk membedakan barang satu dengan barang lainnya dan potensial dilindungi sebagai produk Indikasigeografis menjadi salah satu penyebabnya, sehingga berimplikasi terhadap pemberdayaan dan peningkatan pertumbuhan ekonomi masyarakat. Untuk memperoleh perlindungan hukum Indikasi-geografis, keharusan terdaftar merupakan satu-satunya alternatif yang harus ditempuh sesuai dengan sistem pendaftaran yang dianut oleh UU Merek dan PP Nomor 51 Tahun 2007 tentang Indikasi Geografis yaitu sistem first to file/ sistem konstitutif. ${ }^{6}$ Dalam sistem konstitutif, pendaftar pertamalah yang berhak atas merek (mutatis mutandis terhadap indikasi geografis) dan pihak dialah yang secara eksklusif dapat memakai merek tersebut. Artinya, hak eksklusif atas sesuatu merek diberikan karena adanya pendaftaran (required by registration)

Sebagaimana diatur dalam Pasal 56 ayat (2) UU Merek dan Pasal 2 angka 3 Peraturan Pemerintah Nomor 51 Tahun 2007 tentang Indikasi Geografis, pendaftaran hanya dapat diajukan oleh lembaga yang sengaja dibentuk sebagai pihak Pemohon pendaftaran Indikasi-geografis. Yang dapat menjadi Pemohon pendaftaran Indikasi-geografis adalah: ${ }^{7}$

1. Lembaga yang mewakili masyarakat di daerah yang memproduksi barang yang bersangkutan, yang terdiri atas:

a. pihak yang mengusahakan barang yang merupakan hasil alam atau kekayaan alam;

b. produsen barang hasil pertanian;

c. pembuat barang-barang kerajinan tangan atau hasil industri; atau

d. pedagang yang menjual barang tersebut.

2. Lembaga yang diberi kewenangan untuk itu; atau

3. Kelompok konsumen barang tersebut

Adanya berbagai alternatif pihak yang dapat menjadi pemohon sekaligus pemegang hak perlindungan Indikasi-geografis ini, maka perlu dilakukan persiapan yang matang tentang siapa di antara tiga kemungkinan di atas yang akan ditunjuk salah satunya. Selain penentuan lembaga pemohon

6 Muhamad Jumhana, "Perkembangan Doktrin dan Teori Perlindungan Hak Kekayaan Intelektual", (Bandung: Citra Aditya Bakti, 2006), hal. 74.

${ }^{7}$ Pasal 56 ayat (2) UU Merek dan Pasal 2 angka 3 PP Indikasi Geografis 
pendaftar Indikasi-geografis, pengisian Buku Persyaratan menjadi prasarat mutlak dalam melakukan pendaftaran.

Dalam Pasal 1 angka 9 Peraturan Pemerintah Nomor 51 Tahun 2008 tentang Indikasi Geografis dijelaskan, bahwa Buku Persyaratan adalah suatu dokumen yang memuat informasi tentang kualitas dan karakteristik yang khas dari barang yang dapat digunakan untuk membedakan barang yang satu dengan barang lainnya yang memiliki kategori sama. Buku persyaratan menyangkut seluruh produk baik sejarahnya, metode penanamannya, daerah penanamannya, organisasi yang melakukan penanaman, maupun pengawasan mutunya. ${ }^{8}$

Ubi Cilembu adalah salah satu contoh produk Indikasi Geografis di Indonesia yang belum mendapatkan perlindungan hukum karena belum didaftarkan. ${ }^{9}$ Apabila Ubi Cilembu ini tidak segera didaftarkan, maka akan menimbulkan permasalahan bagi para petani dan pemerintah daerahnya di masa yang akan datang, ${ }^{10}$ yaitu kita harus meminta ijin kepada pemegang hak Indikasi-geografis yang sudah lebih dulu mendaftarkannya. Padahal, Ubi Cilembu merupakan salah satu produk pertanian yang dinilai memiliki keunggulan bagi Pemerintah Kabupaten Sumedang. ${ }^{11}$

8 Buku persyaratan jadi kendala pemohon indikasi geografis $<$ http://www.bisnis.com/servlet/page?_pageid $=127 \&$ dad=portal30\&_schema=PORTAL30\& vnw_lang_id $=2 \&$ ptopik $=A 61 \&$ cdate $=13-$ OCT $-2008 \&$ inw_id $=631403>$.

9. Sampai saat ini masih beredar Ubi Cilembu aspal, asli alias palsu beredar di pasaran. Ubi Cilembu dijual selain di Sumedang maupun di Bandung juga di daerah lain, diantaranya Yogyakarta, Surabaya, Jakarta dan Bali, bahkan sudah sampai ke Jepang dan Malaysia. Oleh perusahaan luar negeri seperti Malaysia, bahan dasar Ubi Cilembu ini dikembangkan menjadi keripik yang dikemas dalam kaleng hampa udara dan diberi nama "sweet potatos". Keadaan yang sama, juga dikembangkan di Jepang, dengan mengolah Ubi Cilembu sebagai makanan sehat bergizi yang diperdagangkan dalam kemasan kardus dengan desain menarik yang diberi merek "Satsumo-Imo", made in Japan, dalam Edi Damian, Arti HKI dan Potensinya sebagai Sumber Ekonomi Jawa Barat, Makalah dalam Seminar Sehari "Pemberdayaan Hak atas Kekayaan Intelektual sebagai Pilar Pembangunan Perekonomian Jawa Barat, Bandung, 31 Mei 2004, hal. 7.

Padahal menurut Daftar Isian Potensi Desa Cilembu, Kecamatan Pamulihan. Pemerintah Kabupaten Sumedang 2006, Ubi Cilembu hanya dipanen setahun sekali. Dari seluas seluas 45 hektar tanaman ubi di daerah Sawah Lega, Sawah Lebak, Pangkalan dan Citali, hasil produksi rata-rata sama yaitu 7 ton/ha atau dalam setahun paling banyak hanya menghasilkan 315 ton.

${ }^{10}$ Eddy Damian, Arti HKI dan Potensinya sebagai Sumber Ekonomi Jawa Barat, Makalah dalam Seminar Sehari "Pemberdayaan Hak atas Kekayaan Intelektual sebagai Pilar Pembangunan Perekonomian Jawa Barat, Bandung, 31 Mei 2004, hal. 7. 
Berdasarkan uraian di atas, ada tiga masalah utama yang menjadi patokan dan fokus sekaligus pembatasan analisis dalam penelitian ini, yaitu:

1. Bagaimana hukum berfungsi dalam menciptakan tergeraknya pertumbuhan ekonomi berupa terciptanya manfaat ekonomi dari perlindungan hukum Indikasi-geografis Ubi Cilembu?

2. Adakah upaya perlindungan hukum Indikasi-geografis yang telah dilakukan oleh masyarakat terkait Ubi Cilembu?

3. Bagaimanakah model lembaga perwakilan untuk pendaftaran Indikasi-geografis seharusnya dibentuk agar relevan dengan kondisi masyarakat petani Ubi Cilembu sehingga perlindungan hukum berupa manfaat ekonomi dapat segera dilaksanakan?

\section{Metode Penelitian}

Penelitian ini adalah penelitian kualitatif. Disebut kualitatif karena sifat data yang dikumpulkan bercorak kualitatif yaitu tidak menggunakan alat-alat pengukur dan statistik. Penelitian kualitatif sendiri adalah tradisi tertentu dalam ilmu pengetahuan sosial yang secara fundamental bergantung pada pengamatan manusia dalam kawasannya sendiri dan berhubungan dengan orang-orang tersebut dalam bahasanya dan dalam peristilahannya. ${ }^{12}$

Penelitian ini termasuk ke dalam sosio-legal research karena menggunakan pendekatan ilmu hukum dan ilmu sosial. Ilmu hukum digunakan untuk mengkaji perlindungan hukum Indikasi-geografis melalui pendaftaran yang diatur dalam PP Nomor 51 Tahun 2007 tentang Indikasi Geografis sehingga dengan adanya peraturan tersebut diharapkan pendaftaran Indikasi-geografis dapat terwujud dan pada akhirnya dapat meningkatkan pertumbuhan ekonomi masyarakat petani Ubi Cilembu berupa terciptanya manfaat ekonomi bagi masyarakat, sedangkan sosiologi digunakan karena mengkaji perilaku masyarakat terhadap perlindungan hukum Indikasigeografis Ubi Cilembu dalam menciptakan manfaat ekonomi masyarakat, dan mengkaji kesadaran masyarakat terhadap upaya perlindungan hukum Indikasi-geografis Ubi Cilembu dalam wujud penentuan pihak yang menjadi pemohon pendaftaran indikasi geografis Ubi Cilembu.

${ }^{11}$ Keputusan Menteri Pertanian No. 124/Kpts/TP.240/2/2001 tentang Pelepasan Ubi Jalar Asal Desa Cilembu Kabupaten Sumedang sebagai Varietas Unggul dengan nama Cilembu.

12 Lexy J. Moleong, "Metodologi Penelitian Kualitatif', Cetakan Kesepuluh, (Bandung: Remaja Rosdakarya), 1999, hal. 3. 
Jadi dalam hal ini, peneliti harus mencoba memahami pola perilaku masyarakat Ubi Cilembu yang masih belum sepakat untuk menentukan pihak yang mewakili semua kepentingan terkait Ubi Cilembu yang menjadi pemohon untuk pendaftaran indikasi geografis Ubi Cilembu.

Paradigma positivisme digunakan dalam penelitian ini untuk memahami realitas sosial yang terjadi pada masyarakat petani Ubi Cilembu dalam upaya meningkatkan manfaat ekonomi dari indikasi geografis Ubi Cilembu. Menurut Agus Salim, ${ }^{13}$ paradigma positivisme melihat hukum sebagai norma-norma yang ajeg sebagaimana tertuang dalam undangundang.

Peneliti akan mengkaji peraturan perundang-undangan yang berkaitan dengan perlindungan hukum Indikasi-geografis yang terdiri dari UndangUndang RI Nomor 7 tahun 1994 tentang ratifikasi WTO Agreement, Undang-Undang RI Nomor 15 Tahun 2001 tentang Merek, Peraturan Pemerintah Nomor 51 Tahun 2007 tentang Indikasi Geografis, dan Keputusan Menteri Pertanian Nomor: 124/Kpts/TP.240/2/2001 tentang Pelepasan Ubi Jalar Asal Desa Cilembu Kabupaten Sumedang sebagai Varietas Unggul dengan nama Cilembu.

Setelah data terkumpul, lalu dilakukan analisis data. Analisis data merupakan proses pencandraan (description) dan penyusunan transkrip interview serta material lain yang telah terkumpul. Maksud dilakukan analisis data agar peneliti dapat menyempurnakan pemahaman terhadap data tersebut untuk kemudian menyajikannya kepada orang lain dengan lebih jelas tentang apa yang telah ditemukan di lapangan. ${ }^{14}$

Peneliti akan menganalisis data secara kualitatif, yaitu secara sistematis dan lengkap, untuk kemudian dikaji dalam bentuk deskripsi yang analitik tanpa mempergunakan rumus yang bersifat matematis. Metode deskriptif analitis akan digunakan untuk menggambarkan fungsi hukum yang tertuang dalam peraturan perundang-undangan dalam menciptakan tergeraknya pertumbuhan ekonomi berupa terciptanya manfaat ekonomi dari perlindungan hukum Indikasi-geografis Ubi Cilembu melalui pendaftaran dan upaya- upaya perlindungan hukum yang telah dilakukan masyarakat petani Ubi Cilembu dan aparat desa maupun kabupaten dalam mengusahakan pendaftaran sampai pada penciptaan model agar pendaftaran Indikasi2006), hal. 15.

${ }^{13}$ Agus Salim, "Teori dan Paradigma Penelitian Sosial", (Yogyakarta: Tiarawacana,

${ }^{14}$ Sudarwan Danim, “Menjadi Peneliti Kualitatif”, (Bandung: Pustaka Setia, 2002), hal. 209-210. 
geografis dapat dilakukan sehingga perlindungan hukum berupa manfaat ekonomi dapat segera dilaksanakan.

Berdasarkan analisis tersebut, kemudian akan dibuat kesimpulankesimpulan secara deduktif. Peneliti akan mengkaji peraturan perundangundangan yang mengatur tentang perlindungan hukum Indikasi-geografis, meneliti perilaku dan kesadaran masyarakat petani Ubi Cilembu tentang perlindungan hukum Indikasi-geografis Ubi Cilembu dan permasalahannya, kemudian menarik kesimpulan dengan menawarkan model pendaftaran untuk mendapatkan perlindungan hukum Indikasi-geografis Ubi Cilembu.

\section{Kondisi Objektif Masyarakat Petani Ubi Cilembu}

\section{A. Kondisi Umum Wilayah Desa Cilembu secara Geografis dan Demografis}

Desa Cilembu adalah sebuah desa yang terletak di Kecamatan Pamulihan, Kabupaten Sumedang, Propinsi Jawa Barat. Letak desa Cilembu berada didaerah perbukitan, di ketinggian 986 meter dari permukaan laut, yang curah hujannya rata rata per tahun $3,528 \mathrm{~mm}$ dengan keadaan suhu rata-rata $320 \mathrm{C}^{15}$ Batas Desa ini meliputi : sebelah Utara berbatasan dengan Desa Cigendel; Selatan dengan Desa Mekarbakti; Barat dengan Desa Haurngombong; dan Timur dengan Desa Cimarias.

Luas wilayah Desa Cilembu sekitar 352,2 hektar yang terbagi untuk kawasan permukiman, pertanian (sawah dan ladang), hutan milik masyarakat, dan perkebunan. Berdasarkan potensi umum, luas tanah sawah secara keseluruhan adalah 137, 9 hektar yang terdiri dari 97,9 hektar sawah irigasi $1 / 2$ teknis dan 40 hektar sawah tanah hujan. Sedangkan luas desa secara keseluruhan adalah sekitar 352,2 hektar yang terbagi untuk tanah sawah, tegalan/ ladang, pemukiman, tanah perkebunan, tanah fasilitas umum, dan tanah hutan. Bedasarkan tipologi, Desa Cilembu termasuk desa sekitar hutan yang terletak di dataran tinggi.

Menurut Daftar Isian Potensi Desa Cilembu, Kecamatan Pamulihan, Pemerintah Kabupaten Sumedang, Tahun 2006, Ubi Cilembu hanya dipanen setahun sekali dengan keterbatasan hasil produksi. Luas tanaman pangan untuk ubi jalar dengan kualitas

${ }^{15}$ Daftar Isian Potensi Desa Cilembu, Kecamatan Pamulihan. Pemerintah Kabupaten Sumedang 2006. 
Nirkum yang selama ini dikenal dengan Ubi Cilembu hanya 45 hektar, dengan hasil produksi sekali panen rata-rata sama yaitu 7 ton/ha. Tanah yang menghasilakan Ubi Cilembu ini hanya terdapat di 4 (empat) blok di Desa Cilembu, yaitu Blok Sawah Lega, Blok Sawah Legok, Blok Pangkalan dan Blok Citali.

Secara demografis, penduduk desa Cilembu berjumlah sekitar 3617 jiwa dari hampir 1000 kepala keluarga. Pada umumnya mata pencaharian penduduk fokus pada pertanian. Dalam status sebagai petani ini, ada yang berkedudukan sebagai pemilik sawah atau tegalan, dan ada juga yang bekerja sebagai penggarap atau buruh tani. Adapun tingkat pendidikan mayoritas umumnya masih rendah, rata-rata lulusan tingkat SD, di samping ada pula lulusan SLTP, SMA, dan juga lulusan Perguruan Tinggi.

Lembaga kemasyarakatan yang konsern terhadap masalah Ubi Cilembu terdiri atas 4 kelompok tani dan 1 asosiasi yaitu Asaguci. ${ }^{16}$ Kelompok tani terdiri dari Kelompok Usaha Tani (KUT) yang dipimpin oleh $\mathrm{Pa}$ Zaman Rukmana, Kelompok Tani Pelopor yang dipimpin oleh Pa Taryana, Kelompok Tani Koperasi Wanita Tani yang dipimpin oleh Ibu Tin, dan kelompok Tani Harapan Pangkalan yang dipimpin Pa Dahlan. Pengusaha/ produsen/ bandar Desa Cilembu terdiri dari Bapak Maman, Bapak Endang, Bapak H. Suryana, dan Bapak Atang. Bapak Taryana selaku ketua Kelompok Tani Pelopor, 5 (lima) tahun terakhir juga merangkap sebagai Bandar. Beliaulah yang pada awalnya merintis pemasaran Ubi Cilembu sampai ke luar negeri, yaitu Jepang.

Awal mula keterlibatan Bapak Taryana dalam pemasaran Ubi Cilembu ke Jepang adalah sejak tahun 1994, Sekolah Pertanian Menengah Atas (SPMA) Tanjungsari Kabupaten Sumedang menjalin kerjasama program magang dengan Pemerintah Jepang. Banyak lulusan SPMA Tanjungsari yang magang di perusahaan-perusahaan di Jepang yang bergerak di bidang pertanian. Pemerintah Jepang meminta pihak SPMA Tanjungsari untuk memberikan produk pertanian yang khas dan istimewa. Pihak SPMA Tanjungsari mengajukan Ubi Cilembu. Sejak itulah tejalin kerjasama dengan pihak Jepang. ${ }^{17}$

${ }^{16}$ Berdasarkan hasil wawancara pada tanggal 27 Mei 2008 dengan Aparat Desa Cilembu yang terdiri dari Kepala Desa Cilembu, yaitu Bapak Koko Kosidin dan Sekdes Cilembu yaitu Bapak Zaman Rukmana, eksistensi Asaguci perlu dipertanyakan lagi, karena dari awal kelahirannya juga tidak jelas, tidak ada koordinasi dengan aparat desa, seolah-olah pendiriannya adalah untuk tujuan suatu kelompok tertentu. 
Dari semenjak tahun 2003 sampai dengan tahun 2006, Bapak Taryana yang merupakan salah satu lulusan SPMA Tanjungsari dan juga pernah magang di Jepang memasarkan/mengekspor Ubi Cilembu ke Jepang. Seiring berjalannya waktu, penjualan Ubi Cilembu ke Jepang tidak dapat dilanjutkan karena tidak bisa memenuhi standar yang ditentukan pihak Jepang.

Sejak saat itu, berbagai cara dilakukan untuk ikut menumpang kepopuleran merek Ubi Cilembu. Upaya-upaya menarik pihak-pihak lain mendiversifikasi Ubi Cilembu semakin banyak dilakukan. Pedagang kios memasukkan ubi kultivar lain yang memiliki kemiripan karakteristik dengan ubi kultivar nirkum ke pasar dengan merek Ubi Cilembu.

\section{B. Karakteristik Ubi Cilembu sebagai Komoditas Andalan Warga Cilembu}

Ubi jalar Cilembu mulai dikenal sekitar dekade tahun 1980-an. Diawali oleh Kepala Desa Cilembu, Kecamatan Pamulihan, ${ }^{18}$ Kabupaten Sumedang, pada waktu itu Alm. Bapak Daud, Kades Desa Cilembu yang melakukan uji coba penanaman ubi jalar di desanya. Hal ini berkaitan dengan potensi lahan, dimana Desa Cilembu dan sekitarnya dikenal subur dan memiliki karakteristik khusus.

Ubi jalar merupakan komoditas andalan bagi penduduk Desa Cilembu. Dari (10) sepuluh kultivar ubi jalar yang ditanam, yang paling menonjol dan menjadi andalan karena rasanya paling enak, lebih manis, dan legit adalah kultivar Nirkum (Meneer Kumpeni). Kultivar ini sudah ada di Sumedang jauh sejak zaman penjajahan Belanda. Kultivar itulah yang belakangan ini dikenal sebagai Ubi Cilembu.

Banyak penduduk Desa Cilembu yang menjadikan Ubi Cilembu sebagai sumber untuk menambah atau memperoleh penghasilan. Banyak juga penduduk Desa Cilembu bekerja sebagai pedagang yang menjajakan Ubi Cilembu di kios-kios di luar Desa Cilembu.

Ubi Cilembu pada umumnya dibudidayakan petani sebagai tanaman penyelang menjelang musim tanam berikutnya. Tanaman pokok mereka pada umumnya padi. Namun, karena sebagian besar lahan pertanian masih tadah hujan, padi hanya ditanam pada saat musim hujan, sekali dalam setahun. Tanaman ubi pada musim hujan

\footnotetext{
${ }^{17}$ Wawancara dengan Bapak Taryana pada 27 Mei 2008.

${ }^{18}$ Sebelumnya masuk ke dalam lingkungan Kecamatan Tanjungsari.
} 
hanya dijumpai di lahan pertanian kering atau kebun. Waktu bertanam ubi jalar cilembu di tanah tegalan, dilaksanakan pada permulaan musim hujan sekitar Bulan Oktober - Desember, sedangkan di tanah sawah dilakukan setelah masa panen tanaman padi sekitar Bulan MeiJuli. ${ }^{19}$

Ubi jalar dapat ditanam pada segala macam tanah dan yang paling cocok adalah pada tanah pasir berlempung yang gembur dan halus. Sebelum pengolahan tanah, dilakukan pengamatan sifat fisik dan kimia tanah. Jika $\mathrm{pH}$ tanah kurang dari 6,0, maka dilakukan pemberian Dolomit sampai $\mathrm{pH}$ tanah mencapai 6,0-7,0. Hasil identifikasi Tim Penelitian Faperta Unwim (1997 - 1998), tanah yang cocok untuk tanaman Ubi Cilembu adalah dari Ordo Inceptisol seperti yang terdapat di Desa Cilembu. Lahan yang paling sesuai adalah lahan sawah setelah panen padi dengan konsistensi gembur dan struktur granular serta banyak mengandung unsur hara makro dan mikro dengan perluasan areal penanaman dapat dilakukan di lahan darat. Keadaan tanah dan lingkungan tempat pembudidayaan Ubi Cilembu adalah sebagai berikut : tinggi tempat $900-1.000 \mathrm{~m} \mathrm{dpl}$, tipe curah hujan C (agak basah), kelembaban udara 74,7\% - 92,9\%, suhu udara berkisar $22,4-23,6^{\circ} \mathrm{C}$, luas pemancaran sinar matahari 70,9-212,7 jam tiap bulan. Kandungan $\mathrm{N}$ total, $\mathrm{P}, \mathrm{Ca}, \mathrm{Mg}, \mathrm{K}, \mathrm{Na}$ masing-masing rendah sampai sedang. ${ }^{20}$

Tanaman ubi jalar cilembu membutuhkan air terutama pada masa pertumbuhan tunas, batang dan daun. Menjelang umbi mulai membesar perlu drainase yang baik (tidak boleh terlalu banyak air) karena dapat menyebabkan umbi membusuk karena hama lanas.

Pemungutan hasil panenan muda dapat dilakukan pada umur 90 95 hari sedangkan panenan tua biasanya pada umur sekitar 120 hari. Umumnya, tanaman musim hujan, waktu panennya lebih lama dari pada tanaman musim kemarau.

Teknologi pasca panen yang dilakukan petani adalah: (1) disimpan di ruang penyimpanan berventilasi baik; (2) ruang penyimpanan difumigasi/ disemprot pestisida sebelum dilakukan penyimpanan ubi jalar dan dilakukan secara berkala; (3) penyimpanan

19 Data dari Dinas Pertanian Tanaman Pangan, Holtikultura, dan Perkebunan Kabupaten Sumedang.

${ }^{20}$ Tim Pengelola Kerjasama LPM - IPB dengan Pemda Kab. Sumedang - Penelitian dan Pengembangan Agrbisnis di Kabupaten Sumedang, 2000. Dalam Sajidin, Faktor-Faktor Kepranataan Yang Mempengaruhi Perkembangan Ubi Cilembu : Kajian Dalam Perspektif Sistem Pasar, Tesis ITB, 2007. 
umbi dilakukan di rak-rak atau menghindari penyimpanan umbi di lantai secara langsung; (4) penyimpanan dalam keranjang bambu dengan alas berupa abu atau pasir kering. Ubi jalar diangin-anginkan selama 2 (dua) hari, lalu ditimbun pada keranjang bambu yang kering dan sejuk. Dasar timbunan diberi alas pasir kering atau abu, lalu di atas timbunan ubi jalar ditutup dengan pasir kering atau abu setebal 20-30 $\mathrm{cm}$. Keuntungan cara ini adalah ubi jalar dapat disimpan sampai 5 (lima) bulan, terbebas dari hama bongleng, juga ubi terasa lebih manis; (5) penyimpanan ubi di ruang gelap dan di dekat dapur atau di kolong rumah.

Teknologi pasca panen lainnya, dapat mengolah ubi Nirkum menjadi produk yang lebih tahan simpan dan membuka peluang pemasaran, yaitu dapat dibuat dodol ubi, keripik ubi, ubi bakar, keremes, dan wajit ubi.

Dalam bagian pertimbangan Keputusan Menteri Pertanian No. 124/Kpts/TP.240/2/2001 tentang Pelepasan Ubi Jalar Asal Desa Cilembu Kabupaten Sumedang sebagai Varietas Unggul dengan nama Cilembu dikemukakan bahwa ubi jalar asal Desa Cilembu, Kabupaten Sumedang, Jawa Barat mempunyai keunggulan rasa manis (jika dibakar dalam oven), warna daging umbi menarik (kulit dan daging umbi berwarna krem kemerahan di waktu mentah dan berwarna kuning bila dimasak), bentuk umbi panjang berurat sangat nyata, mempunyai nilai ekonomis tinggi dan digemari oleh pelaku usaha tani maupun konsumen ubi. Pelepas ubi jalar asal Desa Cilembu sebagai varietas unggul, mempunyai peranan penting dalam rangka usaha meningkatkan produksi ubi jalar.

Deskripsi ubi jalar varietas Cilembu terdiri dari:

Asal

Tipe pertumbuhan

Umur panen

Bentuk daun

Warna daun muda
Desa Cilembu, KecamatanTanjungsari, Kabupaten Sumedang, Jawa Barat

Merambat

$5-7$ bulan

Menjari dengan pinggir daun rata

Hijau keunguan 
Warna daun tua

Warna tulang daun

Warna tangkai daun

Panjang tangkai daun

Warna bunga

Warna batang

Panjang batang

Warna kulit umbi

Warna daging umbi mentah

Warna daging umbi masak

Bentuk umbi

Rasa umbi

Tekstur umbi

Rata-rata hasil

Potensial hasil

Ketahanan terhadap hama dan penyakit

Keunggulan

Daerah adaptasi
Hijau

Bagian bawah hijau keunguan

Hijau dengan lingkar ungu pada bagian ujung

$75-145 \mathrm{~mm}$

Putih keunguan

Hijau

$80-130 \mathrm{~cm}$

Krem kemerahan/ kuning

Krem kemerahan/ kuning

Kuning

Panjang dan berurat nyata

Enak, manis dan bermadu

Baik, tidak berair

$12-17$ ton/ha

20 ton/ha

Tahan penyakit scab/ kudis (elsinoe batatas), peka hama lanas/ penggerek (cilas formicarius)

Bentuk umbi panjang, bobot bahan kering/rendemen umbi tinggi, rasa sangat manis (jika dibakar dalam oven)

Cocok ditanam pada lahan sawah tadah hujan setelah tanam padi pada elevasi 800 $1000 \mathrm{~m} \mathrm{dpl}$

Menurut analisis Laboratorium Teknologi Hasil Pertanian Universitas Pasundan dan Fakultas Pertanian Universitas Widyatama, Bandung, Ubi Cilembu mengandung karbohidrat 60,72 persen, protein $1,4 \%$, lemak $0,7 \%$, gula total $14,16 \%$, sukrose $8,47 \%$, vitamin C 80 
$\mathrm{mg} / 100$ gram, riboflavin $0,4 \mathrm{mg} / 100$ gram, niacin $0,6 \mathrm{mg} / 100$ gram, dan tanin $0,1 \mathrm{mg} / 100$ gram. $^{21}$

\section{Persepsi Masyarakat terhadap perlindungan hukum Indikasi- geografis Ubi Cilembu yang akan dapat memberikan keuntungan ekonomi}

Pengetahuan tentang perlindungan hukum Indikasi-geografis sudah lama dinantikan masyarakat petani Ubi Cilembu. Peneliti memulai penyuluhan tahun 2002 kepada masyarakat petani Ubi Cilembu tentang pentingnya perlindungan hukum Indikasi-geografis Ubi Cilembu. Sejak itu masyarakat menjadi tahu bahwa untuk melindungi Ubi Cilembu digunakan perlindungan hukum Indikasigeografis bukan melalui hak paten. Pengetahuan ini diikuti dengan kesadaran yang lebih baik mengenai pentingnya upaya-upaya kongkrit untuk melindungi Ubi Cilembu dimulai dengan 1) menjaga kualitas dan reputasi Ubi Cilembu secara bersama-sama; 2) berupaya untuk membatasi masuknya ubi jalar dari daerah lain masuk ke wilayah cilembu untuk kemudian seolah-olah dianggap sebagai produk asli cilembu.

Pada tahun 2007, peneliti kembali melakukan penelitian dan penyuluhan lanjutan yang bertujuan mensosialisasikan PP Nomor 51 Tahun 2007 tentang Indikasi Geografis, yang selama ini menjadi kendala mengapa masyarakat petani Ubi Cilembu tidak dapat melakukan pendaftaran. Berdasarkan wawancara yang dilakukan setelah dilaksanakannya penyuluhan hukum lanjutan tentang mekanisme pendaftaran Indikasi-geografis tersebut di atas, tergambar adanya persepsi berbeda-beda pada tiap pihak yang berkepentingan, yaitu petani yang diwakili kelompok tani, produsen/ bandar, dan aparat desa serta aparat pemerintah daerah Kabupaten Sumedang tentang manfaat dan dampak positif yang akan dirasakan apabila pendaftaran untuk melindungi Ubi Cilembu dilaksanakan. Perbedaan ini muncul karena masing-masing pihak mengedepankan kepentingan ekonomi sebagai landasan dalam menerima atau menolak pendaftaran. Hal ini diperburuk dengan kenyataan yang menunjukan sikap saling curiga antara petani dengan bandar, terutama bandar yang telah mempunyai jaringan pemasaran yang luas dan mendapat fasilitas berupa mesin-

21 Wiyana, D dan Akbari, R. Ubi Cilembu Naik Pamor. $<$ http://www.korantempo.com>, diakses tanggal 24 Desember 2004. 
mesin pengolahan modern dari pemerintah daerah Kabupaten Sumedang.

Masyarakat petani beranggapan bahwa pendaftaran Indikasigeografis untuk Ubi Cilembu tidak akan memberikan nilai tambah secara ekonomi bagi petani karena petani tidak memiliki daya tawar yang kuat untuk menentukan harga jual produk. Menurut petani, didaftarkan ataupun tidaknya produk Ubi Cilembu ini sebagai produk Indikasi-geografis tidak penting karena permasalahan yang dihadapi sampai sekarang adalah harga ubi rendah. Padahal, dengan dilakukannya pendaftaran justeru harga jual ubi asli hasil dari wilayah Cilembu akan meningkat karena adanya eksklusifitas.

Persepsi pihak bandar, perlindungan Indikasi-geografis justeru akan membatasi pendapatan mereka karena penjualan sekarang dibatasi hanya untuk ubi asli hasil dari wilayah Cilembu, sehingga terjadi resistensi terhadap anjuran dilakukannya pendaftaran.

Persepsi dari aparat pemerintahan baik di tingkat aparat desa, dinas-dinas terkait maupun pemerintah daerah Kabupaten Sumedang terkesan belum siap. Hal ini dikarenakan secara sosio - kultural, aparat terbiasa menunggu perintah dari atasan ketimbang mengambil inisiatif untuk mendorong terjadinya perlindungan hukum Indikasi-geografis Ubi Cilembu. Hal ini dapat dimengerti karena keterbatasan Sumber Daya Manusia (SDM), keterbatasan anggaran, dan lemahnya koordinasi antar lembaga yang ada di daerah. Selain itu, monitoring dan evaluasi terhadap program pemerintah melalui pemberian bantuan untuk memberdayakan masyarakat Ubi Cilembu berupa mesin-mesin pengolahan modern belum optimal dilakukan sehingga memperlebar disharmoni atau suasana tidak kondusif antara masyarakat petani, produsen/bandar dan aparat Desa Cilembu.

Berdasarkan uraian di atas, peneliti berasumsi pelaksanaan pendaftaran untuk Ubi Cilembu baru dapat dilakukan setelah masalahmasalah internal antar pihak dapat diselesaikan secara musyawahah oleh mereka sendiri untuk menyamakan persepsi.

Tahun 2008, kami melakukan penelitian lanjutan atas biaya dari DIKTI, persepsi masyarakat tentang pentingnya Ubi Cilembu dilindungi sudah mulai muncul. Persepsi masyarakat petani yang pada awalnya menaruh rasa curiga yang berlebihan kepada Bandar apabila Ubi Cilembu didaftarkan sudah mulai memudar. Di Tingkat masyarakat petani dan Bandar sudah mulai mencapai kata sepakat bahwa Ubi Cilembu memang harus dilindungi. 


\section{Kesadaran Masyarakat Terhadap Upaya Perlindungan Hukum Indikasi-Geografis Ubi Cilembu}

Tingkat kesadaran masyarakat dapat dibagi menjadi 2 (dua). Tingkat kesadaran verbal dan tingkat kesadaran yang lahir dari internalisasi akan substansi Indikasi-geografis. Masyarakat yang kami hadapi adalah masyarakat petani dengan tingkat ekonomi dan pendidikan yang relatif rendah. Tipe masyarakat ini lebih mengutamakan kepentingan kolektif dari pada kepentingan individual, sehingga sikap yang muncul adalah menerima apa saja yang disarankan oleh pemerintah daerah, termasuk di dalamnya saran dari peneliti.

Berdasarkan pengolahan data primer dan data sekunder pasca peneliti melakukan penelitian lapangan pada Mei 2008, kesadaran pihak-pihak berkepentingan terkait perlindungan hukum Indikasigeografis Ubi Cilembu yang terdiri dari masyarakat petani yang diwakili kelompok tani, produsen/ bandar, dan aparat Desa Cilembu Kecamatan Pamulihan Kabupaten Sumedang serta aparat pemerintah daerah Kabupaten Sumedang yang diwakili Dinas Pertanian Tanaman Pangan, Holtikultura, dan Perkebunan Kabupaten Sumedang dan Dinas Perindustrian, Perdagangan dan Investasi Kabupaten Sumedang, baru pada tahap verbal. Hal ini dapat dibuktikan dengan mulai munculnya persamaan persepsi/kesepakatan awal dari elemen masyarakat petani dan penjual/pengusaha Ubi Cilembu tentang siapa pihak yang akan menjadi pemohon pendaftaran Indikasi-geografis. Semua masyarakat Desa Cilembu yang diwakili oleh kelompok tani, pedagang/pengusaha, tokoh masyarakat dan aparat Desa Cilembu telah bersepakat bahwa lembaga tersebut didalamnya akan terdiri dari wakil kelompok tani, pedagang/pengusaha, tokoh masyarakat, aparat Desa Cilembu Kecamatan Pamulihan Kabupaten Sumedang serta aparat pemerintah daerah Kabupaten Sumedang yang diwakili Dinas Pertanian Tanaman Pangan, Holtikultura, dan Perkebunan Kabupaten Sumedang dan Dinas Perindustrian, Perdagangan dan Investasi Kabupaten Sumedang serta bagian Hukum Pemkab. Sumedang yang akan menjadi pihak pemohon pendaftaran indikasi geografis Ubi Cilembu.

Akan tetapi, kesadaran tersebut belum merupakan kesadaran hasil dari internalisasi substansi perlindungan hukum Indikasi-geografis Ubi Cilembu. Hal ini terbukti pada pertengahan Juni 2008 merupakan waktu yang ditentukan bersama-sama dengan dinas untuk pelaksanaan pembentukan lembaga pemohon, resistensi pihak terkait di atas dengan 
cara tidak hadir tanpa sebab dan pemberitahuan yang jelas berakibat pembentukan lembaga tersebut gagal dilaksanakan.

Resistensi ini diduga karena sebenarnya masyarakat belum menganggap perlu perlindungan Indikasi-geografis karena masyarakat menilai perlindungan hukum Indikasi-geografis belum memberikan rasa keadilan.

Kesadaran hukum baru tampak pada aparat pemerintah dengan mengupayakan diakuinya keistimewaan Ubi Cilembu melalui Keputusan Menteri Pertanian Nomor: 124/Kpts/TP.240/2/2001 tentang Pelepasan Ubi Jalar Asal Desa Cilembu Kabupaten Sumedang sebagai Varietas Unggul dengan nama Cilembu. Pengakuan tersebut bermanfaat sebagai dokumentasi awal untuk melindungi Ubi Cilembu.

\section{Pembahasan}

\section{A. Indikasi Geografis Sebagai Bagian dari HKI}

Hak Kekayaan Intelektual (HKI) adalah suatu sistem yang melekat pada tata kehidupan modern. Hal ini ditandai dengan tercapainya kesepakatan Negara-negara untuk mengangkat konsep HKI kearah kesepakatan bersama dalam wujud Agreement Establishing the World Trade Organization ("WTO Agreement") dan segala lampirannya, termasuk yang menyangkut HKI. Agreement on Trade Related Aspects of Intellectual Property Rights (TRIP's) adalah salah satu lampiran yang merupakan satu kesatuan yang tidak terpisahkan dengan WTO. ${ }^{22}$ Sejak saat itu, tidak perlu dipungkiri lagi, HKI menjadi sedemikian penting di bidang ekonomi, terutama industri dan perdagangan internasional.

Terlebih di Negara yang sedang berkembang seperti Indonesia, ${ }^{23}$ sistem HKI memegang peranan penting dalam menunjang pembangunan ekonomi melalui penanaman modal dari investor asing. Dengan menciptakan iklim yang kondusif dan aman bagi kegiatan eksploitasi dan komersialisasi HKI, maka akan mendorong investor asing untuk menanamkan modalnya pada kegiatan riset,

${ }^{22}$ Achmad Zen Umar Purba, "Hak Kekayaan Intelektual Pasca TRIPs", Cet. Pertama, (Bandung: Alumni), 2002, hal. 5-6.

${ }^{23}$ Indonesia sebagai negara berkembang sudah menjadi anggota dan sah ikut dalam TRIP's, melalui ratifikasi WTO Agreement dengan Undang-Undang no 7 tahun 1994. Dan diimplementasikan dengan undang-undang HKI nasional Indonesia. 
pengembangan teknologi dan produk-produk baru, ${ }^{24}$ termasuk di dalamnya produk hasil alam serta kerajinan yang penting bagi kelangsungan usaha mereka.

Hubungan antara perdagangan internasional dan HKI telah jelas. Sebagaimana disimpulkan oleh ekonom Keith E Maskus: ${ }^{25}$

I claim that Intellectual Property Rights can play an important and positive role in economic advancement, with the role becoming larger as economies grow richer.Even among poor economies, however, IPRs can be an important conditions of business development, so long as they are well structured and accompanied by appropriate collateral policies. This is the essential challenge as economies adopt stronger IPRs under the new global system.

HKI adalah hak. Sebagai hak, HKI merupakan harta atau asset berupa benda yang tidak berwujud (intangible assets). Salah satu aspek hak khusus pada HKI adalah Hak Ekonomi (economic rights). Hak ekonomi adalah hak untuk memperoleh keuntungan ekonomi atas kekayaan intelektual. Hak ekonomi tersebut berupa keuntungan sejumlah uang yang diperoleh karena penggunaan sendiri HKI, atau karena penggunaan oleh pihak lain berdasarkan lisensi Dengan kata lain HKI adalah objek perdagangan. ${ }^{26}$ Pemilik hak memiliki ekslusivitas yang memungkinkan pihak lain dilarang menggunakan hak tersebut tanpa izin. ${ }^{27}$

${ }^{24}$ Suyud Margono dan Amir Angkasa, "Komersialisasi Aset Intelektual: Aspek Hukum Bisnis", (Jakarta: Grasindo, Jakarta), hal. 53. Komersialisasi HKI dapat melalui:

1. Penjualan atau pengalihan (sale or assignment);

2. Perlisensian (licensing);

3. Joint Ventura Agreement; yang memungkinkan keterlibatan dari elaborasi antara pemerintah dan industri atau universitas dan industri;

4. Waralaba (franchising);

5. Pembelian atau akuisisi; terhadap sebuah kepentingan di sebuah perusahaan yang bekerja di bidang yang relevan, maka sebuah pengembangan teknologi oleh suatu firma dapat dipasarkan oleh perusahaan dengan modal dan jaringan distribusi (distribution networking).

${ }^{25}$ Achmad Zen Umar Purba, Op. Cit. hal. 7.

${ }^{26}$ Abdulkadir Muhammad, "Kajian Hukum Ekonomi Hak Kekayaan Intelektual", Cet. Ke-1, (Bandung: Citra Aditya Bakti, 2001), hal. 19.

${ }^{27}$ Achmad Zen Umar Purba, Op. Cit. hal. 12-13. 
Indikasi-geografis merupakan salah satu bidang HKI. Dalam TRIP's diatur tentang pengaturan yang menyangkut standar-standar bagi perlindungan Indikasi-geografis bagi setiap negara anggota WTO. Indikasi-geografis seperti juga bidang-bidang HKI yang lain sangat berkaitan dengan upaya pencegahan persaingan curang. Hal ini dapat dilihat dari Article 22.2 TRIP's:

In respect of geographical Indications, Members shall provide the legal means for interested parties to prevent:

(a) the use of any means in the designation or presentation of a good that indicaties or suggests that the good in question originates in a geographical area other than the true place of origin in a manner which misleads the publik as to the geographical origin of the good;

(b) any use which constitutes an act of unfair competition within the meaning of article 10bis of the Paris Convention (1967) ${ }^{28}$

Dengan demikian, persetujuan TRIP's membawa akibat timbulnya kewajiban bagi setiap Negara anggota, yaitu setiap pemerintah dari anggota WTO harus menyediakan kesempatan hukum di setiap hukum nasionalnya bagi setiap pemilik Indikasi-geografis yang telah mendaftar di negaranya. Hal ini untuk mencegah penggunaan tandatanda yang sama dengan Indikasi-geografis asli dari suatu produk atau barang. ${ }^{29}$ Pasal 22 TRIP's tersebut mensyaratkan anggotanya untuk menyediakan perlindungan khusus untuk Indikasi-geografis. Di samping itu, juga harus menyediakan cara untuk menghindari penggunaan Indikasi-geografis dengan cara apapun, dalam memberi tanda atau menampilkan barang yang dapat mengindikasikan atau mencitrakan bahwa barang yang diperdagangkan berasal dari suatu wilayah geografis yang bukan dari tempat asal yang sebenarnya. Setiap penggunaan Indikasi-geografis yang mengandung indikasi tindakan kompetisi curang, tunduk ke dalam ketentuan Pasal $10 \mathrm{~b}$ Paris ("TRIPs").

${ }^{28}$ Article 22.2. Agreement on Trade Related Aspects of Intellectual Property Rights

${ }^{29}$ Muhamad Djumhana, Op. Cit., hal. 80-81. 
Convention, ${ }^{30}$ yaitu agar dilakukan perlindungan yang efektif bagi warga Negara dari anggota-anggota Union terhadap persaingan curang. ${ }^{31}$

Indikasi-geografis memberikan perlindungan produk yang kualitas, reputasi atau ciri khas lainnya dipengaruhi oleh kondisi geografis setempat. Hal ini tertuang dalam Article 22.1 TRIP's yang berbunyi, geographical indications are, for the purposes of this agreement, indication which identify a good as originating in the territory of a member, or a region or locality in thet territory, where a given quality, reputation or other characteristic of the good in essentially attributable to its geographical origin.

Indikasi geografis atau juga yang sering disebut dengan istilah appellation of origin, appeliation d'origine, indication of source adalah indikasi atau tanda tanda yang menunjukkan daerah asal suatu barang yang karena faktor lingkungan geografis termasuk faktor alam atau faktor manusia atau kombinasi kedua faktor tersebut memberikan ciri dan kualitas tertentu pada barang yang dihasilkan..$^{32}$ Geographical indication "is a sign used on goods that have a specific geographical origin and process qualities or a reputation that are due to that place of origin". ${ }^{33}$ Indikasi-geografis adalah tanda yang dilekatkan pada barang/ produk hasil alam atau kerajinan yang mempunyai kualitas, reputasi, dan ciri khas karena faktor geografis setempat.

Menurut Pasal 1 angka 1 PP Nomor 51 Tahun 2007 tentang Indikasi Geografis, Indikasi-geografis adalah suatu tanda yang menunjukkan daerah asal suatu barang, yang karena faktor lingkungan geografis termasuk faktor alam, faktor manusia, atau kombinasi dari kedua faktor tersebut, memberikan ciri dan kualitas tertentu pada barang yang dihasilkan.

Jadi Indikasi-geografis adalah suatu indikasi atau identitas dari suatu barang yang berasal dari suatu tempat, daerah atau wilayah tertentu yang menunjukan adanya kualitas, reputasi dan karakteristik

${ }^{30}$ Lihat Helianti Hilman dan Ahdian Romadoni, "Pengelolaan dan Perlindungan Aset Kekayaan Intelektual", The British Council-DFID-ITB, Jakarta, 2001, hal. 127, Lihat juga Achmad Zen Umar Purba, Op.Cit., hal. 76-77.

${ }^{31}$ Dalam Achmad Zen Umar Purba, Ibid., hal. 43.

32 Patricia Loughlan, Intellectual Properti Creative and Marketing Rights, BC Information Service, 1998, hal. 4.

${ }^{33}$ Geographical Indication, <www.wipo,com>, tahun 2004. 
termasuk faktor alam dan manusia yang dijadikan atribut dari barang tersebut. ${ }^{34}$ Yang digunakan sebagai Indikasi-geografis dapat berupa etiket atau label yang dilekatkan pada barang yang dihasilkan tempat, daerah atau wilayah, gambar, huruf dari kombinasi unsur-unsur tersebut. $^{35}$

Sebagai negara tropis yang terletak antara benua Asia dan Australia dan dilewati garis khatulistiwa, Indonesia adalah negara kepulauan yang kaya akan pengetahuan, tradisi, dan budaya, serta iklim tropis yang menghasilkan berbagai macam barang yang memiliki potensi ekonomi yang tidak kecil. Sudah seharusnya Indonesia memiliki sistem perlindungan Indikasi-geografis yang memadai.

\section{B. Perlindungan Hukum Indikasi Geografis melalui Pendafiaran}

Seperti yang dikemukakan Sudargo Gautama di atas, Indikasigeografis adalah suatu indikasi atau atau identitas dari suatu barang yang berasal dari suatu tempat, daerah atau wilayah tertentu yang menunjukan adanya kualitas, reputasi dan karakteristik termasuk faktor alam dan manusia yang dijadikan atribut dari barang tersebut.

Sebagai salah satu objek dalam HKI, Indikasi-geografis baru dapat dilindungi apabila "nama wilayah" yang akan digunakan sebagai tanda pada produk, telah terdaftar (registered) di Direktorat Jenderal HKI. Hal ini tertuang dalam Pasal 56 ayat (2) UU Merek jo Pasal 2 ayat (3) PP Nomor 51 Tahun 2007 tentang Indikasi Geografis, yang intinya menyatakan bahwa "tanda" yang menunjukan "nama wilayah" akan dilindungi sebagai Indikasi-geografis apabila telah terdaftar dalam Daftar Umum Indikasi-geografis di Direktorat Jenderal HKI.

Syarat terdaftar merupakan satu-satunya alternatif untuk mendapatkan perlindungan hukum bagi produk Indikasi-geografis berupa hak eksklusif. Sistem pendaftaran Indikasi-geografis diatur secara mutatis mutandis dengan sistem pendaftaran pada UU Merek. Sistem first to file/ sistem konstitutif ${ }^{36}$ merupakan sistem yang diatur dalam UU Merek. Sistem first to filel sistem konstitutif yang digunakan mengacu kepada Model law for developing countries on Marks Trade names and acts of unfair competition, section 4 yang

${ }^{34}$ Memori Penjelasan Pasal 56 ayat (1) UU Merek.

${ }^{35}$ Sudargo Gautama dan Rizawanto Winata, "Undang-undang Merek Baru Tahun 2001", (Bandung: Citra Aditya Bakti, 2002), hal. 16.

${ }^{36}$ Muhamad Djumha, Op. Cit., hal. 74. 
menyatakan bahwa "The exclusive right to a mark conferred by this law shall be acquired, subject to the following provisions, by registration atau hak eksklusif suatu Merek atau Indikasi-geografis akan diperoleh melalui pendaftaran. ${ }^{37}$ Dalam first to file system/ sistem konstitutif, merek yang terdaftar pertamalah yang berhak atas merek ${ }^{38}$ dan pihak dialah yang secara eksklusif dapat memakai merek tersebut.

Khusus untuk Indikasi-geografis, sebagaimana yang diatur dalam Pasal 56 ayat (2) UU Merek jo Pasal 5 angka (3) PP Nomor 15 Tahun 2007 tentang Indikasi-Geografis, pendaftaran hanya dapat diajukan oleh lembaga yang sengaja dibentuk untuk mewakili sebagai pemegang hak eksklusif Indikasi-geografis. Pasal ini memberi satu syarat bahwa kepemilikan atas suatu Indikasi-geografis, sifatnya nonindividual. Dalam pasal tersebut, dinyatakan bahwa Indikasi-geografis mendapat perlindungan setelah terdaftar atas dasar permohonan yang diajukan oleh:

1. Lembaga yang mewakili masyarakat di daerah yang memproduksi barang yang bersangkutan, yang terdiri atas:

a. pihak yang mengusahakan barang yang merupakan hasil alam atau kekayaan alam;

b. produsen barang hasil pertanian;

c. pembuat barang-barang kerajinan tangan atau hasil industri; atau

d. pedagang yang menjual barang tersebut.

2. Lembaga yang diberi kewenangan untuk itu; atau

3. Kelompok konsumen barang tersebut

Perlindungan hukum Indikasi-geografis yang melekat setelah pendaftaran oleh pihak Pemohon akan berlangsung selama ciri khas masih ada dan/atau kualitasnya dijaga secara terus menerus. Untuk mengetahui masih ada atau tidaknya ciri khas dan kualitas pada suatu produk Indikasi-geografis, PP Nomor 51 Tahun 2007 tentang Indikasi

\section{${ }^{37}$ Ibid.}

${ }^{38}$ Perbedaannya, ada pada kepemilikan. Apabila merek dapat dimiliki oleh pribadi atau badan, sementara kepemilikan atas perlindungan Indikasi-geografis bersifat komunal, bukan individual, artinya terdapat prinsip-prinsip yang harus dipegang, yaitu bahwa komunitas masyarakat setempat memiliki hak untuk mendapatkan pengakuan, perlindungan, pembagian keuntungan, dan hak untuk berpartisipasi dalam pengambilan keputusan. Prinsip hak lainnya yang diakui sebagai hak komunitas masyarakat setempat, yaitu hak moral berupa hak informasi terawal atau lebih dahulu (prior informed concern). Muhamad Djumhana, Ibid., hal. 19-20. 
Geografis mensyaratkan pengisian Buku Persyaratan oleh Pihak Pemohon pendaftar produk Indikasi-geografis. Buku Persyaratan ini berfungsi sebagai pedoman tentang ciri khas/ karakteristik dan kualitas barang. Buku Persyaratan dalam Pasal 1 angka 9 PP Nomor 51 Tahun 2007 tentang Indikasi Geografis, adalah suatu dokumen yang memuat informasi tentang kualitas dan karakteristik yang khas dari barang yang dapat digunakan untuk membedakan barang yang satu dengan barang lainnya yang memiliki kategori sama. Beberapa uraian dalam Buku Persyaratan yang harus diisi pihak Pemohon adalah:

1. nama Indikasi-geografis yang dimohonkan pendaftarannya;

2. nama barang yang dilindungi oleh Indikasi-geografis

3. uraian mengenai karakteristik dan kualitas yang membedakan barang tertentu dengan barang lain yang memiliki kategori sama, dan menjelaskan tentang hubungannya dengan daerah tempat barang tersebut dihasilkan.

4. uraian mengenai lingkungan geografis serta faktor alam dan faktor manusia yang merupakan satu kesatuan dalam memberikan pengaruh terhadap kualitas atau karakteristik dari barang yang dihasilkan;

5. uraian tentang batas-batas daerah dan/atau peta wilayah yang dicakup oleh Indikasi-geografis;

6. uraian mengenai sejarah dan tradisi yang berhubungan dengan pemakaian Indikasi-geografis untuk menandai barang yang dihasilkan di daerah tersebut, termasuk pengakuan dari masyarakat mengenai Indikasi-geografis tersebut;

7. uraian yang menjelaskan tentang proses produksi, proses pengolahan, dan proses pembuatan yang digunakan sehingga memungkinkan setiap produsen di daerah tersebut untuk memproduksi, mengolah, atau membuat barang terkait;

8. uraian mengenai metode yang digunakan untuk menguji kualitas barang yang dihasilkan; dan

9. label yang digunakan pada barang dan memuat Indikasi-geografis

Buku persyaratan tersebut merupakan salah satu dokumen yang menjadi dasar dalam kaitannya dengan Indikasi-geografis, untuk dijadikan bukti kuat mempertahankan penggunaan tanda yang menunjukan nama wilayah dengan cara apapun yang memberikan kesan bahwa barang yang bersangkutan berasal dari wilayah lain di luar wilayah asal barang tersebut.

Apabila Buku Persyaratan ini telah siap, maka produk Indikasigeografis dapat langsung mendaftarkan produknya ke Dirjen HKI. 
Menurut Saky Septiono, Kasi Pemeriksaan Formalitas Indikasi Geografis, Direktorat Merek Ditjen Hak Kekayaan Intelektual, dari proses pendaftaran hingga terbit sertifikat diperkirakan membutuhkan waktu lebih dari dua tahun. Pemeriksaan substantifnya saja maksimal dua tahun, namun dalam praktiknya diperkirakan bisa lebih cepat. ${ }^{39}$

Pemohon yang telah melengkapi Buku Persyaratan dapat mengajukan permohonan pendaftaran ke Dirjen HKI. Dirjen HKI akan melakukan pemeriksaan Administratif atas kelengkapan persyaratan Permohonan sebagaimana dimaksud dalam Pasal 5 dan Pasal 6 dalam waktu paling lama 14 (empat belas) hari terhitung sejak tanggal diterimanya Permohonan. ${ }^{40}$

\section{Manfaat Ekonomi dari Perlindungan Hukum Indikasi Geografis}

Dalam sistem HKI, tercermin adanya jaminan terpeliharanya kepentingan perorangan dan kepentingan masyarakat. ${ }^{41}$ Sebagai cara untuk menyeimbangkan kepentingan antara peranan pribadi individu dengan kepentingan masyarakat, maka sistem HKI berdasarkan pada prinsip keadilan, prinsip ekonomi, prinsip kebudayaan, dan prinsip sosial. $^{42}$

Menurut Frederick Abbott, et.al., isu Indikasi-geografis memiliki dua fungsi. Pertama, fungsi promosi produk yang mempunyai karakter tertentu yang membawa manfaat ke wilayah tempat produk tersebut dibuat (manufactured) atau dipasarkan. Indikasi-geografis dengan

39 Suwantin Oemar, Ditjen HaKI Bahas Biaya Pemeriksaan Indikasi Geografis, <http://haki.depperin.go.id/advokasi-hukum/cetak.php?id=179>, diakses tanggal 16 September 2008. Geografis.

${ }^{40}$ Pasal 7 angka 1 Peraturan Pemerintah Nomor 51 Tahun 2007 tentang Indikasi

${ }^{41}$ Muhamad Djumhana dan Djubaedillah, "Hak Milik Intelektual: Sejarah, Teori dan Prakteknya di Indonesia", (Bandung: Citra Aditya Bakti, 2003).

${ }^{42}$ Afrillyanna Purba, at. al, "TRIP's - WTO \& Hukum HKI Indonesia: Kajian Perlindungan Hak Cipta Seni Batik Tradisional Indonesia", (Jakarta: Rineka Cipta, 2005), hal. 13-14. Berdasarkan prinsip keadilan, maka pencipta sebuah karya, atau orang lain yang bekerja membuahkan hasil dari kemampuan intelektualnya, wajar memperoleh imbalan. Dalam prinsip ekonomi, suatu kepemilikan adalah wajar karena sifat ekonomis manusia yang menjadikan hal itu satu keharusan untuk menunjang kehidupannya di dalam masyarakat. Dalam prinsip sosial, pemberian hak oleh hukum tidak boleh semata-mata untuk memenuhi kepentingan perseorangan, akan tetapi, harus memenuhi kepentingan seluruh masyarakat. 
demikian melindungi produsen di wilayah tersebut terhadap penggunaan yang tidak sah (anauthorized) dari goodwill yang diciptakan oleh kualitas produk itu oleh pesaingnya. Kedua, Indikasigeografis adalah sumber informasi penting untuk konsumen pada pasar yang sangat beragam dalam kaitan dengan asal, kualitas serta reputasi produk yang bersangkutan. ${ }^{43}$

Menurut Emawati Junus, keuntungan bagi petani dari perlindungan Indikasi-geografis adalah meningkatkan profesionalisme petani (karena disyaratkan adanya buku spesifikasi untuk menjamin kualitas), meningkatkan dan memelihara kualitas produk Indikasigeografis dan memperkuat daya saing petani, memperkuat hak petani melalui asosiasi produk Indikasi-geografis (contoh : AEKI), mendorong peningkatan pemerataan ekonomi yang lebih baik bagi para petani, dan meningkatkan dan menciptakan lapangan kerja bagi para petani di daerah yang memiliki potensi produk Indikasigeografis. ${ }^{44}$

Dengan perlindungan hukum Indikasi-geografis ini, bukan berarti tertutup kesempatan bagi pihak lain untuk memanfaatkan produk yang dapat diindikasikan sebagai produk Indikasi-geografis. Melalui perlindungan Indikasi-geografis, maka hanya komoditas/ produk komoditas/ barang yang dihasilkan dari daerah/ wilayah itu saja, yang berhak menggunakan merek dagang Indikasi-geografis. Pihak ketiga siapapun tetap dapat mengunakan merek dagang itu, sepanjang keaslian produk barang tetap dapat dijamin sesuai dengan keluarannya, melalui kebijakan pemberian lisensi atau ijin penggunaan dengan membayar sejumlah uang sebagai bentuk royalty kepada pemegang hak.

Dengan demikian, perlindungan Indikasi-geografis memberikan hak ekonomi sebagai hak kebendaan yang dapat dinilai dengan uang. ${ }^{45}$ Hak ekonomi tersebut, dapat berupa keuntungan sejumlah uang yang diperoleh karena penggunaan sendiri HKI, atau karena penggunaan oleh pihak lain berdasarkan lisensi yang dikembangkan dalam perindustrian atau perdagangan yang juga mendatangkan keuntungan finansial seperti yang telah disebutkan di atas. Hal ini disebabkan karena kepada pemegang HKI diberikan kekuasaan penuh/ monopoli

${ }^{43}$ Ibid, hal. 76-77.

${ }^{44}$ Emawati Junus, Makalah, Jakarta, 6-7 Desember 2004.

${ }^{45}$ Abdulkadir Muhammad, Loc. Cit. 
untuk mengeksplorasi secara ekonomi haknya tersebut. ${ }^{46}$ Pemegang $^{4}$ hak atas Indikasi-geografis dapat mengajukan gugatan terhadap pemakai Indikasi-geografis yang tanpa hak berupa permohonan ganti rugi dan penghentian penggunaan serta pemusnahan etiket Indikasigeografis yang digunakan secara tanpa hak tersebut.

\section{Fungsi Hukum dalam Menciptakan Tergeraknya Pertumbuhan Ekonomi berupa Terciptanya Manfaat Ekonomi dari Perlindungan Hukum Indikasi-geografis Ubi Cilembu}

Hukum tidak hanya berfungsi mengukuhkan pola-pola kebiasaan dan tingkah laku yang terdapat dalam masyarakat untuk mencapai keteraturan dan kepastian, melainkan juga untuk mengarahkan kepada tujuan-tujuan yang yang dikehendaki, menghapuskan kebiasaankebiasaan yang dipandangnya tidak sesuai lagi, dan menciptakan pola kelakuan baru. Fungsi hukum demikian menurut Roscoe Pound harus memuaskan kebutuhan berbagai golongan masyarakat (social engineering), hukum harus mampu memberikan kesejahteraan kepada semua warga masyarakat. Hal tersebut diperkuat oleh pendapat Mochtar Kusumaatmadja, bahwa peranan dan fungsi hukum adalah sebagai alat pembaharuan masyarakat.

Hukum dapat bekerja sesuai dengan fungsinya memberikan kesejahteraan kepada semua warga masyarakat dalam wujud menciptakan tergeraknya pertumbuhan ekonomi masyarakat, apabila adanya pengintegrasian sistem hukum karena hukum harus dipahami dan dikembangkan sebagai satu kesatuan sistem yang di dalamnya terdapat elemen kelembagaan, elemen materi hukum, dan elemen budaya hukum.

Terkait dengan penelitian ini, peneliti mengadopsi pendapat Lawrence M. Friedman. ${ }^{47}$ Menurut Friedman, ada tiga unsur sistem hukum (Three Elements of Legal Sistem) yaitu struktur (lembaga yang memiliki otoritas), substansi (peraturan perundang-undangan) dan kultur hukum (budaya masyarakat). Suatu peraturan dapat berlaku secara efektif memberikan perlindungan hukum bagi masyarakat apabila ketiga unsur hukum tersebut terpenuhi, karena apabila

\footnotetext{
${ }^{46}$ Sunaryati Hartono dan Eli Ermawati, Loc. Cit.
}

${ }^{47}$ Lawrence M. Friedman, "American Law an Introduction, Hukum Amerika: Sebuah Pengantar”, Penerjemah: Wishnu Basuki, (Jakarta: Tatanusa, 2001), hal. 6-8. 
diibaratkan, struktur hukum seperti mesin, substansi adalah apa yang dihasilkan atau dikerjakan oleh mesin itu, dan budaya hukum adalah apa saja atau siapa saja yang memutuskan untuk menghidupkan dan mematikan mesin itu serta memutuskan bagaimana mesin itu digunakan.

PP Nomor 51 Tahun 2007 tentang Indikasi Geografis yang di dalamnya mengatur tentang tata cara pendaftaran Indikasi-geografis menurut pemikiran Freidman di atas berfungsi sebagai substansinya. PP yang merupakan tindak lanjut dari Pasal 56 ayat (9) UU Nomor 15 Tahun 2001 tentang Merek, diharapkan dapat mendorong terjadinya banyak pendaftaran produk-produk Indikasi-geografis di Indonesia termasuk Ubi Cilembu. Berdasarkan sistem pendaftaran first to filel konstitutif, yang menyatakan bahwa pendaftar pertama lah yang mendapatkan perlindungan hukum berupa hak eksklusif, maka tindakan mendaftarkan sesegera mungkin membuka peluang mendapatkan manfaat ekonomi. Dengan didaftarkannya produk Indikasi-geografis, akan menjadi promosi Ubi Cilembu karena memiliki karakteristik dan kualitas khas yang tidak dimiliki ubi jalar yang berasal dari daerah lain, sehingga pada akhirnya akan memberikan manfaat bagi wilayah Desa Cilembu pada khususnya dan Kabupaten Sumedang pada umumnya.

Dengan terdaftarnya Ubi Cilembu, masyarakat petani akan semakin professional menjaga kelestarian karakteristik dan kualitas khas Ubi Cilembu. Melalui pendaftaran akan memunculkan perlindungan hukum dan perlindungan hukum ini akan tetap melekat apabila uraian tentang karakteristik dan kualitas khas yang dituangkan dalam Buku Persyaratan masih tetap terjaga. Secara tidak langsung hal tersebut akan memperkuat daya saing petani. Lebih jauh lagi, apabila profesionalisme masyarakat petani tetap dijaga, maka akan mendorong peningkatan pemerataan ekonomi dan lapangan kerja di bidang pertanian semakin menjanjikan.

Produk Indikasi-geografis yang didaftarkan akan mendapatkan sertifikat, apabila menurut penilaian Tim Indikasi-geografis, poduk tersebut telah memenuhi persyaratan substantif sesuai dengan ketentuan Peraturan Pemerintah Nomor 51 Tahun 2007 tentang Indikasi-geografis. Dari proses pendaftaran hingga terbit sertifikat diperkirakan membutuhkan waktu lebih dari dua tahun.

Pendaftaran produk indikasi geografis akan memberikan nilai tambah dan keuntungan kepada para stakeholders yang terlibat seperti petani dan produsen/ bandar. Konsumen berani membeli produk yang sudah bersertifikat Indikasi-geografis dengan harga mahal karena 
sudah ada standar kualitas dan keunikan dari produk itu. Apabila sudah ada sertifikat, maka pihak lain tidak boleh lagi menggunakan dan menempelkan kata-kata Cilembu pada label produk ubi yang bukan asli berasl dari Desa Cilembu. Sertifikat akan berfungsi sebagai bukti bahwa produk tersebut sudah dilindungi oleh undang undang dan bila ada pihak lain yang menggunakannya, maka hal itu merupakan perbuatan melanggar hukum.

Dalam kenyataannya, menentukan pihak yang dapat merepresentasikan masyarakat untuk menjadi Pemohon pendaftaran Indikasi-geografis sebagai salah satu unsur penting mendapatkan perlindungan hukum melalui pendaftaran, merupakan masalah yang pelik.

Menurut Pasal 5 ayat (3) PP Nomor 51 Tahun 2007 tentang Indikasi Geografis, alternatif pihak yang dapat menjadi Pemohon seperti yang telah disebutkan di atas adalah: a. Lembaga yang mewakili masyarakat di daerah yang memproduksi barang yang bersangkutan, yang terdiri atas: 1) pihak yang mengusahakan barang yang merupakan hasil alam atau kekayaan alam; 2) produsen barang hasil pertanian; 3) pembuat barang-barang kerajinan tangan atau hasil industri; atau 4) pedagang yang menjual barang tersebut. b. Lembaga yang diberi kewenangan untuk itu; atau c. Kelompok konsumen barang tersebut.

Pada prakteknya, ketentuan untuk memilih salah satu dari pihakpihak di atas sebagai pemohon pendaftaran Indikasi-geografis, menimbulkan masalah. Terutama apabila dihadapkan pada kewajiban pengisian Buku Persyaratan. Buku persyaratan adalah suatu dokumen yang memuat informasi tentang kualitas dan karakteristik yang khas dari barang yang dapat digunakan untuk membedakan barang yang satu dengan barang lainnya yang memiliki kategori sama. Buku ini merupakan uraian komprehensif tentang hal-hal substantif dan administratif suatu Indikasi-geografis yang hanya dapat diisi secara bersama-sama oleh pihak-pihak yang disebutkan di atas karena membutuhkan kompetensi dari semua pihak, bukan hanya oleh satu pihak saja sebagaimana yang ditetapkan dalam peraturan.

Sampai saat ini, pembentukan lembaga pemohon pendaftaran yang merupakan kunci untuk mendapatkan perlindungan hukum Indikasi-geografis belum berhasil dilakukan. Seperti yang diuraikan di atas, salah satu penyebabnya terletak pada substansi dari PP Nomor 51 Tahun 2007 tentang Indikasi Geografis, terutama terkait dengan penentuan pihak yang dapat menjadi pemohon pendaftaran Indikasi- 
geografis dihubungkan dengan syarat pengisian Buku Persyaratan, yang hanya dimungkinkan diisi oleh pihak yang memiliki kompetensi.

Selain terkendala oleh substansi, pembentukan lembaga pemohon pendaftaran Indikasi-geografis ini terkendala oleh budaya hukum masyarakat. Seperti yang diungkapkan Friedman, kesadaran masyarakat yang menentukan akan dilindungi atau tidaknya tanda yang menunjukan nama wilayah penghasil produk yang memiliki ciri dan kualitas barang karena faktor geografis termasuk faktor alam, faktor manusia atau kombinasi keduanya. Masyarakat Desa Cilembu yang menentukan apakah ciri dan kualitas Ubi Cilembu akan dipelihara dan dipertahankan dalam jangka waktu tertentu sehingga melahirkan reputasi (keterkenalan) atas barang tersebut, yang selanjutnya memungkinkan Ubi Cilembu memiliki nilai ekonomi tinggi. Masyarakat Desa Cilembu pula lah sebagai Pemohon pendaftar Indikasi-geografis seperti tertuang dalam Pasal 5 ayat (3) PP Nomor 51 Tahun 2007 tentang Indikasi Geografis, yang menentukan apakah Ubi Cilembu harus didaftarkan atau tidak. Jadi, potensi Indikasigeografis dalam meningkatkan pertumbuhan ekonomi masyarakat sangat tergantung dari kesadaran masyarakat untuk melindungi tanda yang menunjukan nama wilayah penghasil produk Indikasi-geografis yang dihasilkan di wilayah mereka melalui pendaftaran ke Dirjen HKI.

Rendahnya tingkat kesadaran masyarakat terkait Ubi Cilembu akan pentingnya perlindungan hukum Indikasi-geografis sedikit banyak dipengaruhi oleh rendahnya tingkat pendidikan masyarakat. Menurut Daftar Isian Potensi Desa Cilembu Tahun 2006, secara demografis, penduduk Desa Cilembu pada umumnya bekerja sebagai penggarap atau buruh tani. Tingkat pendidikan mayoritas umumnya masih rendah, rata-rata lulusan tingkat SD.

Resistensi-resistensi budaya masyarakat terkait Ubi Cilembu berupa:

1. adanya perbedaan persepsi pada tiap pihak yang berkepentingan, yaitu petani yang diwakili kelompok tani, produsen/ bandar, dan aparat desa serta aparat pemerintah daerah Kabupaten Sumedang tentang manfaat dan dampak positif yang akan dirasakan apabila pendaftaran untuk melindungi Ubi Cilembu dilaksanakan.

2. adanya sikap saling curiga antara petani dengan bandar, terutama bandar yang telah mempunyai jaringan pemasaran yang luas dan mendapat fasilitas berupa mesin-mesin pengolahan modern dari pemerintah daerah Kabupaten Sumedang.

3. Keterbatasan ekonomi dan pendidikan masyarakat menyebabkan tingkat kesadaran masyarakat baru pada taraf kesadaran verbal, 
belum pada tingkat kesadaran yang lahir dari internasilasi substansi Indikasi-geografis.

Dengan demikian, tidak ada pilihan lain kecuali masyarakat segera membentuk lembaga yang memenuhi keterwakilan pihak-pihak terkait Ubi Cilembu yang akan bertindak sebagai pemohon pendaftaran. Tindakan ini sebenarnya merupakan refleksi sikap atau budaya masyarakat akan dilindungi atau tidaknya Ubi Cilembu melalui perlindungan Indikasi-geografis. Sikap ini akan ditindaklanjuti dengan menjaga, memelihara dan mempertahankan kualitas dan reputasi yang menjadi ciri khas produk Ubi Cilembu sebagai syarat perlindungan. Jadi potensi ekonomi dari perlindungan hukum Indikasi-geografis dapat dimanfaatkan oleh masyarakat Ubi Cilembu.

Selain masalah di atas, faktor lain yang menyebabkan potensi Indikasi-geografis belum dapat dimanfaatkan secara maksimal untuk menunjang pertumbuhan ekonomi masyarakat, adalah terkait dengan struktur hukum. Lawrence M. Friedman mengibaratkan struktur hukum seperti mesin. Dalam hal ini, peran dan fungsi struktur hukum yang dimaksud adalah aparat Desa Cilembu Kecamatan Pamulihan Kabupaten Sumedang dan pemerintah daerah Kabupaten Sumedang yang diwakili Dinas Pertanian Tanaman Pangan, Holtikultura, dan Perkebunan Kabupaten Sumedang, Dinas Perindustrian, Perdagangan dan Investasi Kabupaten Sumedang, dan bagiah Hukum Pemkab Sumedang. Peran dan fungsi aparat Desa Cilembu dan pemerintah daerah Kabupaten Sumedang dalam mewujudkan perlindungan hukum Indikasi-geografis untuk Ubi Cilembu belum optimal. Secara sosio kultural, umumnya aparat terbiasa menunggu perintah dari atasan ketimbang mengambil inisiatif untuk mendorong terjadinya perlindungan hukum Indikasi-geografis Ubi Cilembu. Faktor-faktor keterbatasan Sumber Daya Manusia (SDM), keterbatasan anggaran, dan lemahnya koordinasi antar lembaga yang ada di daerah menyebabkan fungsi hukum dalam menciptakan tergeraknya pertumbuhan ekonomi berupa terciptanya manfaat ekonomi melalui perlindungan hukum indikasi-geografis Ubi Cilembu belum dapat terlaksana.

Pemerintah Daerah sudah seharusnya memberikan dukungan terwujudnya perlindungan akan hak Indikasi-geografis yang ada di daerahnya, sebagai bentuk kepedulian terhadap kekayaan daerah tersebut dengan menyediakan cara untuk menghindari penggunaan Indikasi-geografis yang tidak sah. Bentuk perlindungan dari pemerintah bagi kepentingan masyarakat dapat dilakukan dengan mendukung usaha masyarakat ke arah pendaftaran dimulai 
denganmembuat pemetaan terhadap produk Indikasi-geografis di daerahnya, menyediakan fasilitas untuk melengkapi persyaratanpersyaratan teknis administratif untuk pendaftaran produk Indikasigeografis, dan sebagai mediator terbentuknya lembaga perwakilan untuk menjadi Pemohon pendaftaran. ${ }^{48}$

Berdasarkan uraian di atas, hukum belum mampu berfungsi sebagai alat pembaharuan masyarakat karena perlindungan hukum Indikasi-geografis Ubi Cilembu yang dapat memberikan kesejahteraan kepada semua warga masyarakat melalui hak ekonomi belum tercapai.

Fungsi hukum yang seharusnya dapat memuaskan kebutuhan berbagai golongan masyarakat dalam hal ini masyarakat petani, produsen/bandar, aparat Desa Cilembu dan pemerintah daerah Kabupaten Sumedang melalui perlindungan hukum Indikasi-geografis belum terpenuhi. Hal tersebut disebabkan oleh tidak terintegrasinya sistem hukum (Three Elements of Legal Sistem) yaitu struktur (lembaga yang memiliki otoritas), substansi (peraturan perundangundangan) dan kultur hukum (budaya masyarakat), sehingga menimbulkan perbedaan pemahaman yang menghambat pengembangan perlindungan hukum Indikasi-geografis Ubi Cilembu.

Salah satu contoh akibat belum berfungsinya hukum khususnya perlindungan hukum Indikasi-geografis adalah munculnya kasus pendaftaran merek Kopi Toraja oleh Key Coffee di Jepang dan pengusaha di Amerika Serikat. Kondisi ini mengakibatkan eksportir Indonesia tidak bisa langsung menjual Kopi Toraja ke Jepang dan Amerika Serikat, kecuali lewat Key Coffee atau pengusaha Amerika Serikat karena jika mengekspor langsung, pihak Indonesia bisa dituding melanggar merek yang telah didaftar di sana.

Dengan demikian, melindungi "nama wilayah" sebagai Indikasigeografis sesuai ketentuan perundang-undangan yang berlaku, menunjukan hukum dapat bekerja sesuai dengan fungsinya yaitu memberikan kesejahteraan kepada semua warga masyarakat dalam wujud menciptakan tergeraknya pertumbuhan ekonomi masyarakat melalui hak ekonomi Indikasi-geografis Ubi Cilembu.

48 Tatty A. Ramli, et,al, Laporan Akhir PKM dengan judul "Penyuluhan Hukum Tentang Tata Cara Pendaftaran Indikasi Geografis Bagi Pihak Petani Ubi Cilembu dan Pemerintah Kabupaten Sumedang, Jawa Barat Sebagai Wujud Sumbangsih Perguruan Tinggi Dalam Rangka Meningkatkan Indeks Pembangunan Manusia (IPM)", LPPM Unisba, 2007. 
E. Upaya Perlindungan Hukum Indikasi-Geografis yang telah Dilakukan oleh Masyarakat Petani dan Aparat/Lembaga di Desa Cilembu

\section{Upaya yang dilakukan Masyarakat Petani}

Pada dasarnya, melindungi Ubi Cilembu melalui mekanisme Indikasi-geografis adalah melakukan pendaftaran, karena sistem pendaftaran yang dianut adalah sistem first to file/ konstitutif yang mengandung arti bahwa perlindungan hanya diberikan kepada Indikasi-geografis yang pertama terdaftar di Dirjen HKI.

Berdasarkan uraian sebelumnya, tingkat kesadaran masyarakat terkait Ubi Cilembu baru pada taraf kesadaran verbal, belum pada tingkat kesadaran yang lahir dari internasilasi substansi Indikasi-geografis, disebabkan keterbatasan ekonomi dan pendidikan masyarakat. Hal ini dapat dilihat dari reaksi positif menerima berbagai informasi dan saran tentang perlindungan hukum Indikasi-geografis dari peneliti. Namun reaksi positif ini tidak identik dengan kesadaran untuk melakukan tindakan perlindungan secara hukum melalui pendaftaran.

Berdasarkan hal itu, menurut hemat peneliti, sampai saat ini upaya-upaya perlindungan hukum Indikasi-geografis oleh masyarakat terkait Ubi Cilembu belum optimal/masih minim.

Pernyataan ini didukung dengan fakta-fakta bahwa:

1) lembaga pemohon pendaftaran yang memenuhi keterwakilan semua pihak belum berhasil dibentuk. Padahal, pemilik Indikasi-geografis adalah Pemohon dan kelompok masyarakat di daerah tempat dihasilkannya barang tertentu yang berkompeten untuk memelihara, mempertahankan, dan memakai Indikasi-geografis sehubungan dengan keperluan bisnis/usahanya.

2) Akibat dari belum terbentuknya lembaga pemohon pendaftaran, maka pengisian Buku Persyaratan Indikasigeografis yang merupakan kewajiban bagi pemohon yang berisi uraian substansi dan administrasi tentang karakteristik dan keistimewaan produk Indikasi-geografis belum dapat terdokumentasikan. Dimana buku tersebut merupakan salah satu dokumen yang menjadi dasar dalam kaitannya dengan Indikasi-geografis, untuk dijadikan bukti kuat mempertahankan penggunaan tanda yang menunjukan nama 
wilayah dengan cara apapun yang memberikan kesan bahwa barang yang bersangkutan berasal dari wilayah lain di luar wilayah asal barang tersebut.

3) Pelanggaran Indikasi-geografis Ubi Cilembu sampai saat ini masih berlangsung, yang mencakup: a) pemakaian suatu tanda Indikasi-geografis yang bersifat komersial, baik secara langsung maupun tidak langsung atas barang yang dilindungi atau tidak dilindungi dengan maksud untuk menunjukkan bahwa barang tersebut sebanding kualitasnya dengan barang yang dilindungi oleh Indikasi-geografis, untuk mendapatkan keuntungan dari pemakaian tersebut, atau untuk mendapatkan keuntungan atas reputasi Indikasi-geografis, dan b) pemakaian Indikasi-geografis yang dapat menyesatkan masyarakat sehubungan dengan asal usul geografis barang itu;

Pelanggaran-pelanggaran ini sangat mungkin terjadi mengingat jumlah Ubi Cilembu yang dijual di pasaran sangat berlimpah, padahal apabila dilihat dari Daftar Isian Potensi Desa Cilembu, Kecamatan Pamulihan, Pemerintah Kabupaten Sumedang, Tahun 2006, Ubi Cilembu hanya dipanen setahun sekali dengan keterbatasan hasil produksi. Luas tanaman pangan untuk ubi jalar hanya 45 hektar, dengan hasil produksi sekali panen rata-rata sama yaitu 7 ton/ha. Jadi mustahil petani Ubi Cilembu dapat memenuhi permintaan pasar sampai ke Yogyakarta, Surabaya, Jakarta dan Bali, bahkan sampai manca negara yakni Malaysia dan Jepang, terakhir Thailand.

Menurut informasi yang ditemukan dalam penelitian, Ubi jalar yang ada di pasaran dengan menggunakan nama "Cilembu" sebagian besar bukan berasal dari tanah Desa Cilembu, melainkan ubi jalar yang dipasok produsen/ bandar dari daerah lain di Jabar, yaitu Cianjur, Rancakalong, Purwakarta, dsb bahkan dari luar Jabar yaitu Lampung. Ubi jalar tersebut diangkut ke dalam wilayah Desa Cilembu agar seolah-olah berasal dari Desa Cilembu.

Melindungi Ubi Cilembu melalui Indikasi-geografis dapat mengurangi perbuatan yang menjurus pada pelanggaran hukum. Apabila dengan perlindungan hukum Indikasi-geografis terjadi perubahan pola pikir, karakter, dan budaya hukum masyarakat, maka fungsi hukum untuk mencerdaskan masyarakat melalui kemampuan menghindari perbuatan yang menjurus kepada pelanggaran hukum, akan menjadi sebuah kenyataan. 


\section{Upaya-upaya Perlindungan Hukum yang Dilakukan Pemerintah Daerah}

Meskipun pemerintah daerah sudah terinformasi tentang perlindungan hukum Indikasi-geografis untuk produk-produk yang memberikan ciri dan kualitas tertentu karena faktor lingkungan geografis termasuk faktor alam, faktor manusia, atau kombinasi dari kedua faktor tersebut, namun upaya-upaya yang mengarah pada terjadinya perlindungan belum dilakukan. Hal tersebut disebabkan oleh karena program perlindungan hukum Indikasi-geografis Ubi Cilembu belum menjadi prioritas dalam perencanaan. Terbukti dengan tidak dialokasikannya dana untuk itu dalam APBD.

Padahal, manfaat ekonomi perlindungan Indikasi-geografis seperti telah disebutkan di atas, hanya dapat dipetik, tatkala ada kepedulian dan tanggungjawab Pemerintah Daerah dalam mengamankan Indikasi-geografis Ubi Cilembu ini. Tindakan kebijakan yang diperlukan dari Pemerintah Daerah Kabupaten Sumedang, adalah menerbitkan Keputusan Kepala Daerah mengenai pembentukan lembaga pemegang hak Indikasigeografis Ubi Cilembu, yang merupakan integrasi semua kepentingan terkait Ubi Cilembu. ${ }^{49}$

Upaya-upaya yang tidak langsung berkaitan dengan perlindungan hukum Indikasi-geografis sudah dilakukan oleh Bagian Hukum Pemerintah Daerah Kabupaten Sumedang, dengan cara mendokumentasikan informasi-informasi karakter khas dan kualitas Ubi Cilembu untuk dapat ajukan sebagai produk yang memiliki varietas unggul kepada Menteri Pertanian melalui Dinas Pertanian Tanaman Pangan, Holtikultura, dan Perkebunan Kabupaten Sumedang.

Hasilnya Menteri Pertanian mengeluarkan Keputusan No. 124/Kpts/TP.240/2/2001 tentang Pelepasan Ubi Jalar Asal Desa Cilembu Kabupaten Sumedang sebagai Varietas Unggul dengan nama Cilembu. Dalam bagian pertimbangan Surat Keputusan Menteri tersebut dikemukakan bahwa ubi jalar asal Desa Cilembu, Kabupaten Sumedang, Jawa Barat mempunyai keunggulan rasa

49 Yeti Sumiyati, et.al, Laporan Akhir Penelitian dengan Judul "Kajian Yuridis Pengaturan Hak Indikasi Geografis Ubi Cilembu Dalam Kerangka Otonomi Daerah", LPPM Unisba, 2007. 
manis (jika dibakar dalam oven), warna daging umbi menarik (kulit dan daging umbi berwarna krem kemerahan di waktu mentah dan berwarna kuning bila dimasak), bentuk umbi panjang berurat sangat nyata. Pelepas ubi jalar asal Desa Cilembu sebagai varietas unggul, mempunyai peranan penting dalam rangka usaha meningkatkan produksi ubi jalar.

Upaya ini merupakan langkah awal yang positif mengingat perlindungan hanya diberikan kepada produk yang mempunyai karakter dan kualitas yang khas. Uraian mengenai karakteristik dan kualitas yang membedakan barang tertentu dengan barang lain yang memiliki kategori sama, dan menjelaskan tentang hubungannya dengan daerah tempat barang tersebut dihasilkan, akan diperiksa oleh Tim Indikasi-geografis sebelum memberikan rekomendasi kepada Dirjen HKI untuk menerima atau menolak permohonan.

Upaya lain yang dilakukan pemerintah daerah Kabupaten Sumedang adalah mendukung setiap penelitian terkait Ubi Cilembu dari sudut pandang ilmu yang beragam antara lain penelitian bidang ilmu hukum, ekonomi, dan pertanian. Salah satunya adalah penelitian yang dilakukan Tim Penelitian Faperta Unwim pada tahun 1997 sampai dengan tahun 1998. Hasil identifikasi Tim Peneliti, tanah yang cocok untuk tanaman Ubi Cilembu adalah dari Ordo Inceptisol seperti yang terdapat di Desa Cilembu. Lahan yang paling sesuai adalah lahan sawah setelah panen padi dengan konsistensi gembur dan struktur granular serta banyak mengandung unsur hara makro dan mikro dengan perluasan areal penanaman dapat dilakukan di lahan darat. Jika $\mathrm{pH}$ tanah kurang dari 6,0, maka dilakukan pemberian Dolomit sampai pH tanah mencapai 6,0 - 7,0.

Dalam Laporan Kerangka Acuan Detail Pengembangan Ubi Cilembu dan Jagung Manis Dinas Pertanian Kabupaten Sumedang, 2006, pada waktu muda tanaman membutuhkan tanah yang cukup lembab. Oleh karena itu, penanaman di musim kemarau harus tersedia air yang memadai. Jika tidak, ubi akan diserang hama penggerek (Cylas $s p$ ) ketika dipanen.

Menurut Tim Pengelola Kerjasama LPM - IPB dengan Pemda Kab. Sumedang - Penelitian dan Pengembangan Agrbisnis di Kabupaten Sumedang, 2000, keadaan tanah dan lingkungan tempat pembudidayaan Ubi Cilembu adalah sebagai berikut : tinggi tempat $900-1.000 \mathrm{~m}$ dpl, tipe curah hujan C (agak basah), kelembaban udara $74,7 \%$ - 92,9\%, suhu udara berkisar 22,4 - 
$23,6^{\circ} \mathrm{C}$, luas pemancaran sinar matahari $70,9-212,7$ jam tiap bulan. Kandungan $\mathrm{N}$ total, $\mathrm{P}, \mathrm{Ca}, \mathrm{Mg}, \mathrm{K}, \mathrm{Na}$ masing-masing rendah sampai sedang.

Penelitian lain yang dilakukan yaitu dari Laboratorium Teknologi Hasil Pertanian Universitas Pasundan dan Fakultas Pertanian Universitas Widyatama, Bandung. Menurut analisis Tim Peneliti, Ubi Cilembu mengandung karbohidrat 60,72 persen, protein $1,4 \%$, lemak $0,7 \%$, gula total $14,16 \%$, sukrose $8,47 \%$, vitamin C $80 \mathrm{mg} / 100 \mathrm{gram}$, riboflavin $0,4 \mathrm{mg} / 100 \mathrm{gram}$, niacin $0,6 \mathrm{mg} / 100 \mathrm{gram}$, dan tanin $0,1 \mathrm{mg} / 100 \mathrm{gram}$.

Tahun 2006, Tim Peneliti dari Lembaga Penelitian Unpad mengidentifikasikan bahwa: 1) karakteristik rasa dan aroma Ubi Cilembu, terkait kuat pada kondisi agroekologisnya, antinya penanaman di tempat lain memerlukan rekayasa tertentu; 2) sentra Ubi Cilembu terletak di tanah bermuatan variabel, yang pemanfaatannya memerlukan teknologi yang berbeda dengan umumnya tanah yang bermuatan tetap; 3) kekhasan produk unggulan suatu daerah tidak terlepas dari kekhasan kondisi iklim mikro dan sumber daya lahan/ tanah daerah tertentu. Dengan demikian, Tim Peneliti Unpad tersebut menyimpulkan, bahwa karakteristik pedon pada areal pertanaman Ubi Jalar Cilembu adalah: 1) komposisi Mineral liatnya didominasi oleh halloisit, pada lapisan permukaan dijumpai halloisit $7 \mathrm{~A}$ sedangkan pada lapisan bawahnya halloisit $10 \mathrm{~A} ; 2$ ) berdasarkan sistem taksonomi tanah, pedon Cilembu dapat diklasifikasikan sebagai Anthraquic Eutrudepts, halus, halloisitik, isohipertemik; dan 3) akibat pola tanam padi sawah - ubi jalar, tanah memiliki kondisi atnrakuik, dijumpai pemadasan lemah pada kedalaman $42-72 \mathrm{Cm}$ yang dapat membatasi laju pergerakan air dan pencucian hara. ${ }^{50}$

Suatu saat nanti, apabila pendaftaran Indikasi-geografis Ubi Cilembu berhasil dilakukan, hasil-hasil penelitian tersebut akan menjadi data awal pengisian Buku Persyaratan tentang hubungan antara karakteristik khas dan kualitas Ubi Cilembu dengan daerah tempat barang tersebut dihasilkan dan pengaruh lingkungan geografis.

Upaya lain yang dilakukan adalah Pemerintah daerah melalui Dinas Perdagangan, Perindustrian dan Investasi telah memberikan

${ }^{50}$ Laporan Hasil Penelitian Lembaga Penelitian Unpad, Model Ameliorasi Tanah Variabel untuk Mendukung Pengembangan Ubi Cilembu di Kabupaten Sumedang, 2006. 
fasilitas berupa alat-alat pengolahan untuk meningkatkan nilai komersil Ubi Cilembu. Dinas terkait juga telah melakukan pemetaan terhadap seluruh potensi usaha Kabupaten Sumedang termasuk di dalamnya potensi yang dilindungi Indikasi-geografis.

\section{F. Model Alternatif Lembaga Perwakilan untuk Pendaftaran Indikasi-geografis yang Relevan dengan Kondisi Masyarakat Petani Ubi Cilembu agar Terwujudnya Perlindungan Hukum Indikasi-Geografis berupa Manfaat Ekonomi bagi masyarakat terkait Ubi Cilembu}

Salah satu langkah awal untuk mempersiapkan persyaratan teknis administratif adalah memfasilitasi terbentuknya model lembaga Pemohon pendaftar Indikasi-geografis yang terintegrasi. Diperlukan koordinasi antara pemerintah dengan masyarakat terkait dengan pengisian Buku Persyaratan yang akan menjadi pertimbangan dalam pemeriksaan substantif oleh Tim Ahli Indikasi-geografis.

Mengingat pemilik Indikasi-geografis adalah kelompok masyarakat di daerah tempat dihasilkannya barang tertentu yang berkompeten untuk memelihara, mempertahankan, dan memakai Indikasi-geografis sehubungan dengan keperluan bisnis/ usaha, maka model lembaga yang terintegrasi harus dibentuk dari konstituen masyarakat Ubi Cilembu.

Penulis menyarankan lembaga yang akan menjadi pemohon pendaftaran Indikasi-geografis Ubi Cilembu adalah model lembaga yang dapat mengintegrasikan semua kepentingan stakeholders. Lembaga dimaksud adalah gabungan perwakilan dari 1) lembaga yang mewakili masyarakat di daerah yang memproduksi barang yang bersangkutan, yang terdiri atas: pihak yang mengusahakan barang yang merupakan hasil alam atau kekayaan alam; produsen barang hasil pertanian; pembuat barang-barang kerajinan tangan atau hasil industri; atau pedagang yang menjual barang tersebut; 2) lembaga yang diberi kewenangan untuk itu, dalam hal ini pemerintah daerah dan 3) kelompok konsumen barang yang dapat diindikasikan sebagai produk Indikasi-geografis.

Sebagaimana yang dijelaskan dalam Penjelasan Pasal 4 ayat (3) PP Nomor 51 Tahun 2007 tentang Indikasi Geografis, bentuk lembaganya antara lain mencakup koperasi, asosiasi, atau yayasan, yang anggotanya adalah produsen setempat. Bentuk lembaga yang diusulkan peneliti adalah Koperasi. Pertimbangan hukum pemilihan 
bentuk koperasi sebagai bentuk lembaga pemohon pendaftaran Indikasi-geografis adalah:

1. Koperasi adalah bentuk badan usaha yang akrab/ familiar sampai lapisan masyarakat terbawah;

2. Status badan hukum koperasi memberikan kepastian tentang pertanggungjawaban lembaga dalam mengelola manfaat ekonomi dari kepemilikan hak Indikasi-geografis;

3. Tujuan badan usaha koperasi adalah mensejahterakan anggota koperasi;

4. Koperasi adalah lembaga usaha yang pembinaan dan pengawasannya dilakukan oleh pemerintah.

Koperasi melalui anggota-anggota yang berasal dari gabungan perwakilan lembaga ketika akan mengajukan permohonan pendaftaran Indikasi-geografis, mempunyai kewajiban mengisi Buku Persyaratan. Buku tersebut berfungsi sebagai pedoman/ patokan yang dapat dijadikan bukti kuat untuk menghindari penggunaan "nama wilayah" untuk produk yang bukan asli berasal dari daerah tersebut.

Uraian yang harus diisi dalam Buku Persyaratan sebagai syarat utama pendaftaran, hanya dapat dilakukan oleh pihak-pihak yang mempunyai kompetensi terhadap informasi yang akan diuraikan. Sehingga sekali lagi ditegaskan model integrasi yang berbentuk koperasi harus terdiri dari perwakilan a) lembaga yang mewakili masyarakat di daerah yang memproduksi barang yang bersangkutan, yang terdiri atas: pihak yang mengusahakan barang yang merupakan hasil alam atau kekayaan alam; produsen barang hasil pertanian; pembuat barang-barang kerajinan tangan atau hasil industri; atau pedagang yang menjual barang tersebut; b) lembaga yang diberi kewenangan untuk itu, dalam hal ini pemerintah daerah dan c) kelompok konsumen barang yang dapat diindikasikan sebagai produk Indikasi-geografis.

Unsur-unsur keterwakilan dalam koperasi sebagaimana dijelaskan di atas akan relevan apabila disadari bahwa uraian dalam Buku Persyaratan terdiri dari keterangan substantif dan administratif Ubi Cilembu, sehingga:

1. hanya masyarakat petani yang memiliki kompetensi menguraikan mengenai sejarah dan tradisi yang berhubungan dengan pemakaian Indikasi-geografis untuk menandai barang yang dihasilkan di daerah tersebut. 
1. Konsumen yang memiliki kompetensi untuk memberikan pengakuan/testimoni mengenai keunggulan produk Indikasigeografis

2. Menjadi kompetensi Dinas Pertanian untuk memberikan uraian mengenai karakteristik khas dan kualitas yang membedakan barang tertentu dengan barang lain yang memiliki kategori sama, dan menjelaskan tentang hubungannya dengan daerah tempat barang tersebut dihasilkan; uraian mengenai pengaruh lingkungan geografis dan alam serta faktor manusia terhadap kualitas atau karakteristik barang tersebut; dan uraian tentang batas-batas wilayah dan/atau peta daerah yang dilindungi oleh Indikasigeografis;

3. Produsen/pengusaha/bandar mempunyai kompetensi menjelaskan tentang proses produksi, proses pengolahan, proses pembuatan yang digunakan sehingga memungkinkan setiap produsen di daerah tersebut dapat memproduksi, mengolah, atau membuat barang terkait;

4. Pemerintah daerah cq bagian Hukum Kabupaten Sumedang memiliki kompetensi dalam hal pengurusan birokrasi pemerintahan terkait dengan proses pendaftaran Indikasi-geografis ke Dirjen HKI.

Usulan struktur organisasi koperasi sebagai lembaga yang akan mewakili masyarakat mendaftarakan dan mengelola hak Indikasigeografis Ubi Cilembu, mencakup:

1. Pembina yang terdiri dari unsur pemerintahan baik di tingkat desa maupun pemerintah kabupaten.

2. Pengurus, yang ketuanya dipilih dari unsur kelompok tani Pelopor yang sekaligus merupakan produsen/bandar Ubi Cilembu, mengingat tugasnya selain melakukan pendaftaran juga membangun koordinasi dengan petani desa guna menjamin pemasaran.

3. Pengawas, yang terdiri dari asosiasi konsumen seperti YLKI Kabupaten Sumedang, Kadin daerah Kabupaten Sumedang, dan Dinas Pertanian daerah Kabupaten Sumedang.

Dengan demikian, model alternatif lembaga perwakilan untuk pendaftaran Indikasi-geografis yang relevan dengan kondisi masyarakat petani ubi cilembu agar terwujudnya perlindungan hukum Indikasi-geografis berupa manfaat ekonomi bagi masyarakat terkait Ubi Cilembu adalah model integrasi. Mekanisme model integrasi lembaga perwakilan untuk pendaftaran Indikasi-geografis adalah: 1) 
ati berkoordinasi untuk mendirikan group manajemen Indikasi-geografis Ubi Cilembu yang melibatkan aparat Desa Cilembu, aparat pemerintah Kabupaten Sumedang, kelompok tani, produsen/ bandar, dan tus: kelompok konsumen; 2) persiapan pengisian Buku Persyaratan tex: diantaranya: mendeskripsikan karakteristik Ubi Cilembu, membangun iti: keterkaitan dengan asal geografiknya yang melibatkan aparat Desa Cilembu, aparat pemerintah Kabupaten Sumedang, kelompok tani, produsen/ bandar; 3) penentuan bentuk lembaga pemohon pendaftar Indikasi-geografis Ubi Cilembu yang melibatkan aparat Desa Cilembu, aparat pemerintah Kabupaten Sumedang, kelompok tani, produsen/ bandar, dan kelompok konsumen; dan 4) persiapan regulasi yang melibatkan pemerintah.

Apabila model integrasi lembaga perwakilan ini terbentuk, maka pendaftaran dapat segera dilakukan. Dengan demikian perlindungan hukum Indikasi-geografis yang memberikan manfaat ekonomi bagi masyarakat dapat terwujud.

\section{Simpulan dan Saran}

\section{A. Simpulan}

Hukum belum dapat berfungsi dalam menciptakan tergeraknya pertumbuhan ekonomi berupa terciptanya manfaat ekonomi dari perlindungan hukum Indikasi-geografis Ubi Cilembu karena Ubi Cilembu belum didaftarkan. Faktor-faktor penyebab belum didaftarkannya Ubi Cilembu sebagai produk yang dilindungi sebagai Indikasi-geografis antara lain belum terintegrasinya sistem hukum (Three Elements of Legal Sistem) yaitu struktur (Pemerintah Daerah Kabupaten Sumedang dan Aparat Desa Cilembu), substansi (PP Nomor 51 Tahun 2007 tentang Indikasi Geografis) dan kultur hukum (budaya masyarakat terkait Ubi Cilembu), sehingga menimbulkan perbedaan pemahaman yang menghambat pengembangan perlindungan hukum Indikasi-geografis Ubi Cilembu. Ketiadaan pendaftaran tidak akan melahirkan perlindungan hukum berupa hak eksklusif dari Indikasi-geografis.

Upaya-upaya perlindungan hukum Indikasi-geografis Ubi Cilembu menghadapi berbagai resistensi baik dari masyarakat maupun 'birokrasi pemerintahan akibat keterbatasan tingkat pendidikan, ekonomi, dan sosio - cultural. Hal ini disebabkan karena kesadaran masyarakat terkait Ubi Cilembu baru pada taraf kesadaran verbal, belum pada tingkat kesadaran yang lahir dari internasilasi substansi 
Indikasi-geografis sehingga tindakan perlindungan secara hukum melalui pendaftaran belum terjadi.

Model integrasi yang paling mendekati tataran ideal adalah lembaga yang memenuhi keterwakilan semua kepentingan, yang melibatkan aparat Desa Cilembu, aparat pemerintah Kabupaten Sumedang, kelompok tani, produsen/ bandar, dan kelompok konsumen. Dengan terintegrasinya lembaga pemohon pendaftaran tersebut diharapkan pengisian Buku Persyaratan yang menuntut kompetensi para pihak dapat dilakukan. Bentuk lembaga tersebut adalah koperasi yang ketua pelaksananya akan dipilih dari unsur kelompok tani Pelopor karena tugasnya selain memastikan pendaftaran Indikasi-geografis juga menjamin pengelolaan hak ekonomi yang muncul dari perlindungan hukum.

\section{B. Saran}

Mengingat tingkat kesadaran masyarakat masih pada tataran verbal, belum terinternalisasi menjadi tindakan hukum, maka perlu terus dilakukan diseminasi tentang 1) pentingnya perlindungan hukum Indikasi-geografis Ubi Cilembu yang akan memberikan manfaat ekonomi berupa kesejahteraan seluruh masyarakat terkait Ubi Cilembu; dan 2) model integrasi berupa lembaga yang memenuhi keterwakilan semua kepentingan yang paling ideal menjadi pemohon pendaftar Indikasi-geografis Ubi Cilembu. 


\section{Daftar Pustaka}

\section{Buku-buku}

Danim, Sudarwan. Menjadi Peneliti Kualitatif, Bandung: Pustaka Setia, 2002 .

Djumhana, Muhamad. Perkembangan Doktrin dan Teori Perlindungan Hak Kekayaan Intelektual, Bandung: Citra Aditya Bakti, 2006. . dan Djubaedillah, Hak Milik Intelektual: Sejarah, Teori dan Prakteknya di Indonesia, Bandung: Citra Aditya Bakti, 2003.

Gautama, Sudargo, dan Rizawanto Winata, Undang-undang Merek Baru Tahun 2001, Bandung: Citra Aditya Bakti, 2002.

Hartono, Sunaryati, Hukum Ekonomi Pembangunan Indonesia, Bandung: Binacipta, 1988.

Hilman, Helianti, dan Ahdian Romadoni, Pengelolaan dan Perlindungan Aset Kekayaan Intelektual, The British Council-DFID-ITB, Jakarta, 2001.

Kusumaatmadja, Mochtar, dan Arief Sidharta. Pengantar Ilmu Hukum, Suatu Pengenalan Pertama Ruang Lingkup Berlakunya Ilmu Hukum, Buku I. Bandung: Alumni, 2000.

. Fungsi dan Perkembangan Hukum. Fakultas Hukum Unpad, Bandung, 1970.

. Konsep-konsep Hukum dalam Pembangunan, Bandung: Alumni, 2002.

M. Friedman, Lawrence. American Law an Introduction, Hukum Amerika:

Sebuah Pengantar, Penerjemah: Wishnu Basuki, Jakarta: Tatanusa, 2001.

Margono, Suyud, dan Amir Angkasa, Komersialisasi Aset Intelektual: Aspek Hukum Bisnis, Jakarta: Grasindo,2002.

Moleong, Lexy J. Metodologi Penelitian Kualitatif, Cetakan Kesepuluh, Bandung: Remaja Rosdakarya, 1999.

Muhammad, Abdulkadir. Kajian Hukum Ekonomi Hak Kekayaan Intelektual, Cet. Ke-1, Bandung: Citra Aditya Bakti, 2001.

Patricia Loughlan, Intellectual Properti Creative and Marketing Rights, BC Information Service, 1998. 
Purba, Achmad Zen Umar. Hak Kekayaan Intelektual Pasca TRIPs, Cet. Pertama, Bandung: Alumni, 2002.

Purba, Afrillyanna, et. al, TRIP's - WTO \& Hukum HKI Indonesia: Kajian Perlindungan Hak Cipta Seni Batik Tradisional Indonesia, Rineka Cipta, Jakarta, 2005.

S. Nasution. Metodologi Penelitian Naturalistik Kualitatif. Bandung: Tarsito, 1996.

Salim, Agus. "Teori dan Paradigma Penelitian Sosial", Yogyakarta: Tiarawacana, 2006.

Soemitro, Ronny Hanitijo. Metodologi Penelitian Hukum dan Jurimetri. Jakarta: Ghalia Indonesia, 1994.

\section{Peraturan Perundang-undangan}

Undang-Undang Nomor 15 Tahun 2001 tentang Merek

Peraturan Pemerintah Nomor 51 Tahun 2007 tentang Indikasi Geografis

Keputusan Menteri Pertanian No. 124/Kpts/TP.240/2/2001 tentang Pelepasan Ubi Jalar Asal Desa Cilembu Kabupaten Sumedang sebagai Varietas Unggul dengan nama Cilembu.

Agreement on Trade Related Aspects of Intellectual Property Rights ("TRIPs").

\section{Makalah dan Hasil Penelitian}

Bapeda Kabupaten Sumedang dan LPM - IPB, Penelitian dan Pengembangan Agribisnis di Kabupaten Sumedang, 2000.

Dinas Pertanian Kabupaten Sumedang dan Balai Pengkajian Teknologi Pertanian Jawa Barat, Kerangka Acuan Detail Design Pengembangan Ubi Cilembu dan Jagung Manis. 2006.

Emawati Junus, Pentingnya Perlindungan Indikasi Geografis sebagai Bagian dari HKI dan Pelaksanaannya di Indonesia, Makalah pada Seminar Nasional "Perlindungan Indikasi Geografis di Indonesia, Jakarta, 6-7 Desember 2004.

Eddy Damian, Arti HKI dan Potensinya sebagai Sumber Ekonomi Jawa Barat, Makalah pada Seminar Sehari "Pemberdayaan Hak atas 
Kekayaan Intelektual sebagai Pilar Pembangunan Perekonomian Jawa Barat," Bandung, 31 Mei 2004.

Deno Kamelus, Fungsi Hukum terhadap Ekonomi di Indonesia, Ringkasan Disertasi, Pascasarjana Unair, Surabaya, 1992.

Kamil Idris, Kekayaan Intelektual, Sebuah Kekuatan untuk Pertumbuhan Ekonomi, World Intellectual Property, 2004.

Laporan Hasil Penelitian Tim Penelitian Faperta Unwim 1997 - 1998.

Laporan Hasil Penelitian Lembaga Penelitian Unpad, Model Ameliorasi Tanah Variabel untuk Mendukung Pengembangan Ubi Cilembu di Kabupaten Sumedang, 2006.

Sajidin, Faktor-Faktor Kepranataan Yang Mempengaruhi Perkembangan Ubi Cilembu : Kajian Dalam Perspektif Sistem Pasar, Tesis ITB, 2007.

Tim Pengelola Kerjasama LPM - IPB dengan Pemda Kab. Sumedang Penelitian dan Pengembangan Agrbisnis di Kabupaten Sumedang, 2000 .

Tatty A. Ramli dan Yeti Sumiyati, Laporan Akhir PKM dengan judul "Perlindungan Hukum Indikasi Geografis bagi petani Ubi Cilembu, Kecamatan Tanjungsari, Kabupaten Sumedang, Jawa Barat"., LPPM Unisba, 2002.

Tatty A. Ramli, et,al, Laporan Akhir PKM dengan judul "Penyuluhan Hukum Tentang Tata Cara Pendaftaran Indikasi Geografis Bagi Pihak Petani Ubi Cilembu dan Pemerintah Kabupaten Sumedang, Jawa Barat Sebagai Wujud Sumbangsih Perguruan Tinggi Dalam Rangka Meningkatkan Indeks Pembangunan Manusia, LPPM Unisba, 2007.

Yeti Sumiyati, et,al, Laporan Akhir Penelitian dengan Judul "Kajian Yuridis Pengaturan Hak Indikasi Geografis Ubi Cilembu Dalam Kerangka Otonomi Daerah", LPPM Unisba, 2007.

\section{Data Kondisi Umum Desa}

Daftar Isian Potensi Desa Cilembu, Kecamatan Pamulihan. Pemerintah Kabupaten Sumedang 2006

\section{Surat Kabar}

Harian Umum Galamedia, Selasa 26 Juni 2007. 


\section{Sumber Internet}

"Buku persyaratan jadi kendala pemohon indikasi geografis", $<$ http://www.bisnis.com/servlet/page? pageid=127\&_dad=portal 30\&_schema $=$ PORTAL30\&vnw_lang id $=2 \&$ ptopik $=$ A61\&cdat $\mathrm{e}=13-$ OCT-2008\&inw_id=631403>, 13 Oktober 2008.Solihat, K. "Hati-Hati Memilih Ubi Cilembu", <http://www.pikiran-rakyat.com>, 19 Mei 2005.

"Ditjen Haki Bahas Biaya Pemeriksaan Indikasi Geografis", <http://haki.depperin.go.id/advokasi-hukum/cetak.php?id=179>, Suwantin Oemar Bisnis Indonesia, 16 September 2008.

"Geographical Indication", <www.wipo,com>, tahun 2004.

"Kopi Kintamani Bali didaftarkan ke Direktorat Merek", $<$ http://www.dgip.go.id/ebscript/publicportal.cgi?.ucid=376\&ctid=23 \&id=1748\&type $=>$, Suwantin Oemar, Bisnis Indonesia. 18 Januari 2008.

"Peningkatan Nilai Tambah Komoditas Indonesia Dengan Pengembangan Indikasi Geografis, Direktorat Kerjasama Dan Perdagangan Internasional 2004", <http://ditjenkpi.depdag.go.id/website_kpi/files/ content/2/Indikasi_Geografis_Final20060106141403.doc>.

Wiyana, D dan Akbari, R. "Ubi Cilembu Naik Pamor", <http://www.korantempo.com>, 24 Desember 2004. 